\title{
Critical multi-stranded approach for determining the ecological values of diatoms in unique aquatic ecosystems of anthropogenic origin
}

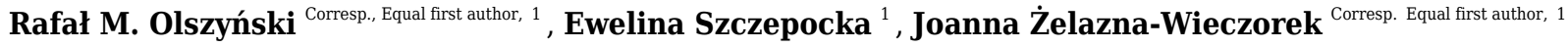 \\ ${ }^{1}$ Department of Algology and Mycology, Faculty of Biology and Environmental Protection, University of Lodz, Łódź, Poland \\ Corresponding Authors: Rafał M. Olszyński, Joanna Żelazna-Wieczorek \\ Email address: rafal.olszynski@biol.uni.lodz.pl, joanna.zelazna@biol.uni.lodz.pl
}

Background. The ecological state of surface waters is typically assessed by a multiaspect approach based on a determination of its chemical and physical parameters, by hydromorphology and the use of indicator organisms such as benthic diatoms. By assigning ecological indicator values, it is possible to create diatom indices which serve as the basic tool in assessing the ecological status of surface waters. These ecological indicator values are set according to classification systems, such as the Van Dam et al. 1994 system, which classifies species of diatoms according to seven different ecological factors. However, recent studies on the autecology of diatoms have shown the need to verify and establish new ecological indicator values. To this end, aquatic ecosystems are good environments to observe the range of tolerance of benthic diatoms to environmental conditions due to their unique physical and chemical parameters. The aim of the present study was to propose the establishment of new, or altered, ecological indicator values, according to Van Dam et al. classification, of species of diatoms characteristic of three post-mining aquatic ecosystems. Methods. In total, 36 species were identified that were characteristic of three waterbodies: a salt aquatic complex (water outflow, a drainage ditch and a pond), a mined iron ore reservoir and a mined lignite reservoir. Their ecological indicator values were calculated using OMNIDIA software, and the environmental conditions prevailing in the studied ecosystems were determined. Of the 36 characteristic species, 16 lacking at least one assigned ecological indicator value were analysed further. The analysis identified three groups of selected characteristic species which showed a correlation, or lack of such, to the tested physical and chemical parameters. Results. Based on this multistage study of the autecology of characteristic diatoms, comprising an analysis of environmental conditions, literature analysis and reference ecological indicator values of other species, it is proposed that 32 ecological indicator values be established or adjusted for 16 species, and that Planothidium frequentissimum be excluded from water 


\section{Critical multi-stranded approach for determining the}

2 ecological values of diatoms in unique aquatic

3 ecosystems of anthropogenic origin

4

5

6 Rafał M. Olszyński, Ewelina Szczepocka, Joanna Żelazna-Wieczorek

7

8 Department of Algology and Mycology, Faculty of Biology and Environmental Protection,

9 University of Lodz, Łódź, Poland

11 Corresponding Authors:

12 Rafał M. Olszyński

13 12/16 Banacha St, Łódź, 90-237, Poland

14 Email address: rafal.olszynski@biol.uni.lodz.pl

Joanna Żelazna-Wieczorek

17 12/16 Banacha St, Łódź, 90-237, Poland

18 Email address: joanna.zelazna@biol.uni.lodz.pl

19 


\section{Abstract}

21 Background. The ecological state of surface waters is typically assessed by a multi-aspect approach based on a determination of its chemical and physical parameters, by hydromorphology and the use of indicator organisms such as benthic diatoms. By assigning ecological indicator values, it is possible to create diatom indices which serve as the basic tool in assessing the ecological status of surface waters. These ecological indicator values are set according to classification systems, such as the Van Dam et al. 1994 system, which classifies species of diatoms according to seven different ecological factors. However, recent studies on the autecology of diatoms have shown the need to verify and establish new ecological indicator values. To this end, aquatic ecosystems are good environments to observe the range of tolerance of benthic diatoms to environmental conditions due to their unique physical and chemical parameters. The aim of the present study was to propose the establishment of new, or altered, ecological indicator values, according to Van Dam et al. classification, of species of diatoms characteristic of three post-mining aquatic ecosystems.

Methods. In total, 36 species were identified that were characteristic of three waterbodies: a salt aquatic complex (water outflow, a drainage ditch and a pond), a mined iron ore reservoir and a mined lignite reservoir. Their ecological indicator values were calculated using OMNIDIA software, and the environmental conditions prevailing in the studied ecosystems were determined. Of the 36 characteristic species, 16 lacking at least one assigned ecological indicator value were analysed further. The analysis identified three groups of selected characteristic species which showed a correlation, or lack of such, to the tested physical and chemical parameters.

Results. Based on this multistage study of the autecology of characteristic diatoms, comprising an analysis of environmental conditions, literature analysis and reference ecological indicator values of other species, it is proposed that 32 ecological indicator values be established or adjusted for 16 species, and that Planothidium frequentissimum be excluded from water quality assessments.

\section{Introduction}

Diatoms (Bacillariophyta) are one of the main biotic elements used in the biological assessment of the ecological state of surface waters (Water Framework Directive, European Union 2000). Due to the fact that many countries are obliged to continually engage in biomonitoring, there is a clear need to develop flawlessly functioning methods based on the standardised use of diatoms as bioindicators (Kahlert et al. 2016; Poikane, Kelly \& Cantonati 2016; Szczepocka \& ŻelaznaWieczorek 2018). Diatom indices and ecological systems based on the bioindication values of particular diatom species, derived from various environmental parameters, constitute a fundamental tool in the biological assessment of environments. Diatom indices have been commonly used to assess flowing and standing water for over 20 years (Kelly et al. 2008; Harding \& Taylor 2014; Szczepocka et al. 2014; Hutorowicz \& Pasztaleniec 2014; Holms \& 
59 Currently, many countries use the OMNIDIA program (Lecointe et al. 1993) as a biological

60

61

62

63

64

65

66

67

68

69

70

71

72

73

74

75

76

77

78

79

80

81

82

83

84

85

86

87

88

89

90

91

92

93

94

95

96

97

assessment tool. Its latest version (version 6.0.6) allows the calculation of 18 diatom indices, and the determination of seven environmental parameters for eight ecological systems. However, the specific ecological indicator values of many of the species given in the OMNIDIA database are absent or have not been updated in response to recent research. To complete these missing values, and to verify existing ones, further studies are needed of the ecological optima and tolerance of diatom species in different types of aquatic ecosystems.

Due to their specific environmental conditions, post-mining reservoirs represent an extremely valuable source of information for the study of ecological diatom tolerance ranges. Some studies of these environments have been performed, but these have addressed diatom paleoecology and their role as indicators of past climatic or environmental change (de Haan et al. 1993; Rakowska 1996; Thomas \& John 2006; Sienkiewicz \& Gasiorowski 2016). Until now, the autecology of diatoms in post-mining reservoirs has rarely been studied (Van Landingham 1968; de Haan et al. 1993; Rakowska 1996; Ferreira da Silva et al. 2009; Luís et al. 2009; Luís et al. 2016;

Sienkiewicz \& Gasiorowski 2016).

The present study examines the diatom assemblages present in three post-mining reservoirs of various geological origins. Due to variations in their environmental parameters, these bodies of water serve as specific and unique habitats for the development of these algae. The diatom assemblages quickly adapt to the currently prevailing conditions, which is manifested in the presence of taxa characteristic of these specific parameters. Considering their large share of the assemblage, the index values of the assemblages constitute the most important component in the calculation of diatom indices. These species are therefore of the greatest importance for surface water biomonitoring.

The aim of the present study was to identify the species of diatoms characteristic of the three studied types of post-mine reservoirs. Following this, taxa that did not have at least one ecological indicator value specified in the OMNIDIA database, according to the environmental parameters given by Van Dam et al. (1994), were identified. New ecological indicator values were proposed based on the relationship between the occurrence of the individual species and certain selected physical and chemical parameters, or existing ones were verified.

The Van Dam et al. (1994) ecological system is one of the main systems on which the OMNIDIA programme is based. It describes the ecological indicator values of diatoms according to $\mathrm{pH}$, salinity, nitrogen uptake metabolism, oxygen requirement, saprobity, trophic state and moisture aerophily. These values play a key role in calculating diatom indices, and hence need to be kept up to date to enable accurate routine biomonitoring.

\section{Materials \& Methods}

\section{Study area}

The study was performed on three waterbodies created through exploration for mineral deposits or were formed by the closure of mines. All three are located in the Eódzkie and Wielkopolskie voivodeships, Central Poland.

PeerJ reviewing PDF | (2019:05:37496:2:0:NEW 22 Oct 2019) 
98 The first complex of waterbodies - Pełczyska (PE), is situated in the village of Pełczyska, 99 between Łódź and Łęczyca (Łódzkie voivodeship) (Fig. 1). As the local area is characterized by 100 the presence of salt deposits, numerous wells were sunk in the eighteenth century to obtain brine. 101 Currently, salt water flows out of one of them. This area has been studied by biologists and 102 hydrobiologists since the 1960s (Olaczek 1963; Pliński 1966; Pliński 1969; Pliński 1971a; 103 Pliński 1971b; Pliński 1971c; Pliński 1973; Żelazna-Wieczorek 1996; Żelazna-Wieczorek 2002; 104 Żelazna-Wieczorek, Olszyński \& Nowicka-Krawczyk 2015; Żelazna-Wieczorek \& Olszyński

105 2016). The waterbodies chosen for our research form the PE hydrological complex located in the 106 vicinity of farmland; it comprises the salt water outflow, a drainage ditch and a pond, which acts 107 as the receiver of the water.

108 The second complex of waterbodies - Łęczyca (LE), urban reservoirs located within the city of 109 Łęczyca (Łódzkie voivodeship) (Fig. 1). The reservoirs were created following the flooding the 110 open-cast iron ore mine in the 1990s. This area is rich in syderite deposits, which are 111 accompanied by other minerals. The complex consists of three connected reservoirs: two are 112 directly connected to each other (LEP1 and LEP2), and the third (LEP3) is connected to LEP2 113 via a water drainage ditch (Olszyński \& Żelazna-Wieczorek 2018). All three are located in an 114 area with houses, garden plots and partly-wooded areas.

115 The third waterbody - Bogdałów reservoir (BO), created by the flooding of an opencast brown 116 coal mine. It is located in the village of Bogdałów (Wielkopolskie voivodeship) in an area rich in 117 lignite deposits (Fig. 1). Lignite from quaternary deposits was exploited since 1977 until 1991 to 118 a depth of 50 meters. Due to the specific construction of the open-pit area, being characterised by 119 the thickest layer of poorly permeable boulder clay in the region. This pit was later transformed 120 into a storage site for quarried rocks in Koźmin. Finally, in 1993/1994, the drainage and runoff 121 of surface waters were blocked to form a reservoir with a depth of about 12 meters surrounded 122 by forest (Gabryś-Godlewska et al. 2004; Gadomska et al. 2007; Orlikowski \& Szwed 2009; 123 Kasztelewicz 2011).

124 Samples

125 Samples of benthic diatoms from sediments and water samples were collected quarterly (once in any season) from each hydrological waterbodies. Analysis of all water samples $\left(\mathrm{Ca}^{2+}, \mathrm{Mg}^{2+}, \mathrm{Na}^{+}\right.$, $\mathrm{K}^{+}, \mathrm{Fe}^{2+/ 3+}, \mathrm{Mn}^{3+}$ ) involved flame absorption spectrophotometry SpectrAA 300 (Varian, Palo Alto, CA, USA) (detection limit is $0.05 \mathrm{mg} / \mathrm{L}$ ) and UV-vis spectrophotometry S.330 (Marcel, Poland) in the case of $\mathrm{NH}_{4}{ }^{+}$(d.1. is $\left.0.001 \mathrm{mg} / \mathrm{L}\right)$ and $\mathrm{PO}_{4}{ }^{3-}$ (d.1. is $0.01 \mathrm{mg} / \mathrm{L}$ ). $\mathrm{SO}_{4}{ }^{2-}$ was determined by the gravimetric method (PN-C-04566-09), $\mathrm{Cl}^{-}$by Mohr's method (PN-ISO 9297). The chemical analyses were performed in the Laboratory of the Department of Geology at the Faculty of Geographical Sciences, University of Łódź and the Laboratory of Computer and Analytical Techniques at the Faculty of Biology and Environmental Protection, University of 135 Łódź. The water temperature, $\mathrm{pH}$ and electric conductivity were measured in situ (Elmetron CP401 and CC-401 devices). The following sampling points were established: 
136 Pełczyska (5158'34.47"N; 19¹4'21.11"E) - outflow (P.ESB.) (4 samples, both water and 137 benthic), ditch (D.PEDB.) (1 water and 4 benthic samples) and pond (D.PEPB.) (4 samples, both 138 water and benthic); samples were collected quarterly from July 2013 to March 2014;

139 Łęczyca (52॰3'5.30"N; 19¹1'50.24"E) - reservoir 1 (D.LEP1.), reservoir 2 (D.LEP2.) and

140 reservoir 3 (D.LEP3.), samples were collected quarterly from March 2014 to December 2015 (6

141 water and 8 benthic samples from each reservoirs);

142 Bogdałów (52²'51.29"N; 18³5'51.49"E) - reservoir (D.BOZB.), samples were collected

143 quarterly from March 2015 to December 2016 (8 samples, both water and benthic).

144 In total, 44 benthic samples were collected. The permanent slides were prepared according to

145 Żelazna-Wieczorek (2011). To obtain pure diatom frustule the material was chemically treated

146 using a $\mathrm{H}_{2} \mathrm{SO}_{4}$ and $\mathrm{H}_{2} \mathrm{Cr}_{2} \mathrm{O}_{7}$. The cleaned diatom precipitate was mounted on permanent slides

147 using Naphrax ${ }^{\circledR}$ synthetic resin.

148 Qualitative and quantitative analysis of diatoms was performed using a Nikon Eclipse 50i light

149 microscope (LM) under 1000× magnification (plan oil-immersion objective 100×/1.25): the

150 diatoms were identified and counted for up to 500 valves in each permanent slide. Light

151 photomicrographs were taken with an OPTA-TECH digital camera.

152 When diatoms were difficult to identify using LM they were subjected to scanning electron

153 microscope (SEM) analysis using a Phenom Pro X (gold layer of 8 and $20 \mathrm{~nm}$, at $10 \mathrm{kV}$, low

154 vacuum mode) at the Laboratory of Microscopy Imaging and Specialist Biological Techniques,

155 Faculty of Biology and Environmental Protection, University of Lodz.

156

157

158

159

160

161

162

163

164

165

166

167

168

169

170

171

172

173

174

\section{Data processing \& statistical analysis}

The average percentage (AP) for a given species was determined based on the percentage contribution (\%) of the species in the samples tested for a given hydrological object (ŻelaznaWieczorek 2011). Species whit AP greater than or equal to 5\% for each hydrological object were identified as dominant.

The incidence was determined according to the Tümpling \& Friedrich (1999) coefficient according to the range values: $100 \%-75 \%$ euconstant taxa (EC), $75 \%-50 \%$ constant taxa (CN), $50 \%-25 \%$ accessory taxa (AC) and $25 \%-1 \%$ accidental taxa (AD) (Tümpling \& Friedrich 1999).

Multidimensional scaling analysis (nMDS) based on Bray-Curtis similarity coefficients was used to identify natural groupings of samples. The results are given as a 3D diagram in which the degree of similarity is represented as the distances between particular points (samples), with greater distances indicating a lower degree of similarity. The reliability of the ordering of the assemblage is represented by the stress value, which reflects how well the ordination summarizes the observed distances among the samples. A 3-dimensional presentation, whose stress value is lower, is likely to be more satisfactory than a 2-dimensional one (Clarke \& Gorley 2015).

The Shade Plot analysis, based on the Bray-Curtis similarity coefficient, was used to identify the diatom species that have the strongest influence on the similarities between the samples demonstrated in the nMDS analysis. Shade Plot analysis compares two data matrices with each

Peer) reviewing PDF | (2019:05:37496:2:0:NEW 22 Oct 2019) 
175 other and then groups them on two levels, according to the similarity of the samples and the 176 factors affecting their similarity, i.e. diatom species. The results are represented graphically by 177 shading individual cells: the intensity of the shading indicates the degree of the influence of a 178 given factor (species) on the position of its sample within a given similarity cluster. The range of 179 the shading was determined on the basis of $\log (\mathrm{x}+1)(\mathrm{x}-$ number of valves).

180 The SIMPER analysis was used to determine the characteristic species distinguishing the studied 181 ecosystems. This method examines the participation of each variable in the overall similarity 182 between groups of samples, thus indicating the species with the greatest influence on the degree 183 of similarity, or dissimilarity, between particular samples and hydrological objects. This analysis 184 is also based on the Bray-Curtis similarity coefficient; however, unlike the nMDS method, in 185 which one trial is compared to all the other samples, the SIMPER analysis compares a single sample to each subsequent sample (Żelazna-Wieczorek 2011). The results indicate the species which most strongly differentiated a sampled site from the others, and to what extent. A species was regarded as being characteristic of the studied ecosystem if it was characterized by a mean dissimilarity greater than or equal to 2 according to the SIMPER analysis, and a higher mean abundance greater in one ecosystem than the other.

In total, 19 physical and chemical parameters of water were measured in the studied ecosystems. The results of the correlation analysis found 15 physical and chemical parameters indicating an environmental conditions. The parameters were subjected to principal component analysis (PCA) to determine which had the strongest effect on the selected species.

Using the information from the OMNIDIA database, the environmental conditions for each sampling point were determined according to Van Dam et al. (1994) (Table S1). Following this, the percentage share of diatom species included in each ecological indicator value class was indicated. For species found to be characteristic of the studied ecosystems, classes of ecological indicator values were assembled. Taxa which had at least one value of 0 (unknown) were selected for further analysis.

The selected ecological indicator values according to Van Dam et al. (1994) were verified, or new ones established, for the species found to be characteristic of the studied ecosystems according to three premises: previous literature reports about ecological indicator values of those species, chemical and physical conditions analysis, and the classification of the environmental conditions according to Van Dam et al. (1994).

The analyses were performed using PRIMER 7.0.13 (nMDS, Shade Plot, SIMPER), OMNIDIA 6.0.6 and STATISTICA 13 (PCA), software.

\section{Results}

\section{Chemical analysis of water samples}

210 The mean values and range of all tested parameters are given in Table 1.

211 The PE hydrological complex was characterized by elevated values of electric conductivity, 212 reaching as high as $9230 \mu \mathrm{S} \mathrm{cm}^{-1}$. The $\mathrm{pH}$ changed with the direction of water outflow: a slightly 213 acidic reaction was observed in the outflow and an alkaline one in the pond. Due to the 
214 geological profile of the region, the water flowing out of the well contained a high concentration 215 of chloride ions, whose gradient decreased with the flow of water through the ditch to the pond.

216 In addition, higher concentrations of the cations $\mathrm{Mg}^{2+}, \mathrm{Ca}^{2+}, \mathrm{Na}^{+}$and $\mathrm{K}^{+}$were observed

217 compared to other ecosystems, as well as the anions $\mathrm{HCO}^{3-}, \mathrm{PO}_{4}{ }^{3-}$ and $\mathrm{SO}_{4}{ }^{2-}$.

218 The $\mathrm{K}^{+}$concentration is acknowledged parameter coming from agricultural activity, in particular 219 animal husbandry, or municipal wastes (Macioszczyk \& Dobrzyński 2002).

220 Each of the sampling points in the PE complex was characterized by different chemical 221 parameters, resulting in differences between the habitats. The highest electrolytic conductivity 222 was noted in the outflow, which was mainly influenced by the concentrations of $\mathrm{Cl}^{-}, \mathrm{Na}^{+}$and $223 \mathrm{HCO}^{3-}$ ions. The maximum concentration of $\mathrm{HCO}^{3-}$ ions was recorded in Pełczyska ouflow in 224 March 2014 (D.PESB.250314); in the other locations, it did not exceed $410 \mathrm{mg} \mathrm{L}^{-1}$. 225 Low concentrations of $\mathrm{K}^{+}$ions were observed throughout the entire studied PE complex;

226

227

228

229

230

231

232

233

234

235

236

237

238

239

240

241

242

243

244

245

246

247

248

249

250

251

252

however, maximum values were recorded in the locations characterised by the highest $\mathrm{HCO}^{3-}$ ion content. The highest concentration of $\mathrm{Ca}^{+}$ions of all ecosystems was recorded in the outflow.

The ditch represented an intermediate section between the PE sampling points. However, as it is susceptible to periodic drying, limited chemical data was collected from this habitat and hence it was not possible to assess its chemical and physical nature.

The lowest electrolytic conductivity was found in the pond, which displayed lower concentrations of $\mathrm{Cl}^{-}, \mathrm{Na}^{+}$and, to a lesser degree, $\mathrm{HCO}^{3-}$. The $\mathrm{pH}$ of the water never dropped below 8, except in one case in March 2014. In the pond, the concentration of $\mathrm{K}^{+}$remained relatively unchanged, which could be related to the fact that the reservoir was also a receiver of waters flowing from the surrounding arable fields. The pond was also characterized by the lowest concentration of $\mathrm{Ca}^{2+}$ and $\mathrm{Mg}^{2+}$. In the summer periods, a significant reduction in the water table level and occasional drying of the reservoir were noted.

The urban reservoirs in Łęczyca (LE) were characterized by a slightly alkaline water reaction, which was similar in all reservoirs during the course of the study. No elevated concentrations of $\mathrm{Fe}^{2+/ 3+}$ and $\mathrm{Mn}^{3+}$ ions were observed. The content of $\mathrm{SO}_{4}{ }^{2-}$ anions was not higher than in other waterbodies studied. The concentration of $\mathrm{HCO}^{3-}$ ions was lower than that observed in $\mathrm{BO}$ and PE. No significant differences in chemical and physical parameters were observed between the individual sampling points constituting LE.

The Bogdałów (BO) reservoir was characterized by an alkaline reaction. It's $\mathrm{K}^{+}, \mathrm{Cl}^{-}$and $\mathrm{NH}^{4+}$ ion content was the lowest of the studied ecosystems.

\section{Diatom samples}

A total of 381 diatom taxa were identified in 44 benthic samples: 139 in PE, 192 in LE and 188 in BO. The dominant species in PE were Navicula veneta, and Nitzschia frustulum, in LE Cyclostephanos dubius and Stephanodiscus hantzschii, in BO Achnanthidium minutissimum, Pantocsekiella ocellata and Mastogloia smithii. In the examined ecosystems, the most commonly identified classes were accidental (PE-84; LE-111; BO-86), accessory (PE-25; LE35) and euconstant taxa (BO-39) (Fig. S1).

PeerJ reviewing PDF | (2019:05:37496:2:0:NEW 22 Oct 2019) 
253

254

255

256

257

258

259

260

261

262

263

264

265

266

267

268

269

270

271

272

273

274

275

276

277

278

279

280

281

282

283

284

285

286

287

288

nMDS analysis

nMDS analysis (stress level $=0.07$ ) identified the variation between samples for each studied hydrological object (Fig. 2). The samples taken from BO constitute a separate cloud, with the samples demonstrating high similarity with each other, whereas the samples of D.LEP1, D.LEP2 and D.LEP3 constitute a distinct group, with no clear differentiation into individual reservoirs. In the case of PE, the pond group (D.PEPB) was found to be clearly distinct from the others.

Shade Plot

Shade Plot analysis identified 50 species which had the strongest influence on the degree of similarity, or non-similarity, between the samples in the studied ecosystems. Of these taxa, the 11 that most strongly influenced the similarity between the samples in at least two ecosystems were Navicula veneta (NVEN), N. cincta (NCCA), $N$. gregaria (NGRE), Nitzschia frustulum (NIFR), N. inconspicua (NINC), N. palea (NPAL), Planothidium frequentissimum (PLFQ), Amphora pediculus (APED), Cyclotella meneghiniana (CMEN), Fragilaria radians (FRAD) and Achnanthidium minutissimum (ADMI) (Fig. 3).

SIMPER analysis

SIMPER analysis allowed 36 species characteristic of the tested hydrological objects to be distinguished (Table 2). In addition, two species were found to be characteristic of two different ecosystems: Achnanthidium minutissimum for LE and BO and Nitzschia palea for PE and LE.

\section{Ecological analysis based on Omnidia software}

The ecological analysis of diatom assemblages based on data obtained from the OMNIDIA program database, indicated the following:

- pH requirements: while alkaliphilic species predominate in PE (63\%), a large percentage in D.PEPB are unknown (24\%) or neutrophilic species (23\%). The LE reservoirs were dominated by alkalibiontic (45\%) and alkaliphilic (24\%) organisms. In D.LEP1, 25\% of species were unknown. BO was dominated by alkaliphilic (39\%) and neutrophilic (29\%) species, and $26 \%$ of species were unknown (Fig. S2);

- salinity: the PE complex was characterized by the occurrence of halophilic (43\%), oligohalobous (30\%) and mesohalobous species (16\%); the greatest proportion of the mesohalobous species were found in D.PESB (28\%). The LE reservoirs were dominated by oligohalobous (44\%) and halophilic species (42\%). BO was dominated by oligohalobous (43\%), halophobe (24\%) and unknown species (23\%) (Fig. S2);

- nitrogen uptake: the most common species in the PE complex N-autotrophic tolerant (39\%) followed by unknown (25\%). The largest percentage of unknown species $(28 \%)$ was recorded in D.PEPB and D.PEDB. In the LE reservoirs, the most common groups of species were Nautotrophic (57\%) and unknown (25\%). In BO, 51\% species were unknown, 24\% were Nautotrophic tolerant and $22 \% \mathrm{~N}$-autotrophic sensitive (Fig. S2); 
289

290

291

292

293

294

295

296

297

298

299

300

301

302

303

304

305

306

307

308

309

310

311

312

313

314

315

316

317

318

319

320

321

322

323

324

325

326

327

- oxygen requirements: in PE, the largest groups of species were low oxygen (30\%), unknown $(27 \%)$ and moderate oxygen (24\%). In LE, oxybiontic species were most common $(43 \%)$ followed by unknown (25\%). In BO, unknown (46\%) and polyoxybiontic species (42\%) predominated (Fig. S2);

- sensitivity to saprobity: in PE, the largest group of taxa were $\alpha$-meso: polysabrobe $(28 \%)$ and unknown (23\%). In D.PEPB, the most abundant was $\alpha$-meso-polysabrobe $(34 \%)$ followed by $\beta$ mesosaprobe (31\%) and unknown (27\%). LE primarily included taxa from the $\alpha$-mesosaprobe group (47\%) and unknown (23\%). In BO, unknown (34\%), $\beta$-mesosaprobe $(31 \%)$ and oligosaprobe taxa (28\%) predominated (Fig. S2);

- trophic status: in PE, the largest group of diatoms were eutrophic (50\%) and unknown taxa (25\%), LE had the highest percentage (61\%) of eutrophic species but also unknown (15\%) and hypereutrophic (13\%) were present. In BO, the most abundant species were unknown (42\%), indifferent (19\%) and meso-eutrophic (16\%) (Fig. S2);

- moisture aerophily: in PE, the largest group was aquatic to aerophilic (56\%), representing 66\% of species in D.PESB, $61 \%$ in D.PEDB, and $42 \%$ in D.PEPB. The second largest group was unknown (23\%), constituting 32\% of taxa in D.PEPB. In LE, 37\% of the species were aquatic (24\% of taxa in D.LEP2), $54 \%$ were occasionally aerophilic and $22 \%$ were unknown. In BO, the predominant groups of species were unknown (44\%) and aquatic to aerophilic (33\%) (Fig. S2).

\section{Characteristic species: OMNIDIA and PCA analysis}

The analysis of species characteristic of the tested ecosystems, determined according to Van Dam et al. (1994), identified 16 taxa classified as 0 in at least one category (Table 3). The next step determined the percentage contribution of each of these species classified as class 0 for the ecological parameters defined by Van Dam et al. (1994) at each sampling point (Table S2). The principal components analysis (PCA) was performed to find the relationships between the abiotic parameters and the characteristic species $(n=36)$ (Fig. 4). The Eigenvalues Plot method given eigenvalues above $1 \%$, showed that 12 factors account for $83,2 \%$ of the total variance. The first two factors account for $31,3 \%$ of the total variance. Based on the PCA analysis for of the 16 characteristic taxa mentioned above and physical and chemical parameters, the following relationships were demonstrated:

- Group A: Chamaepinnularia krookiformis, C. plinskii, Nitzschia liebethruthii and Planothidium delicatulum demonstrate a negative correlation with $\mathrm{pH}$ and a positive correlation with a decrease in the concentrations of $\mathrm{HCO}^{3-}, \mathrm{Ca}^{2+}$ and $\mathrm{Fe}^{2+/ 3+}$ (Fig. 4). - Group B: Craticula buderi, Planothidium frequentissimum and Navicula cincta did not demonstrate any relationship with any water parameters (Fig. 4).

- Group C: Navicula moskalii, Cyclostephanos invisitatus, Stephanodiscus parvus, S. binatus, Diatoma moniliformis, Nitzschia dissipata var. media, Mastogloia smithii, Pantocsekiella pseudocomensis and Encyonopsis subminuta demonstrated a negative correlation with a decrease in electrolyte conductivity, as well as with the concentrations of $\mathrm{K}^{+}, \mathrm{Mg}^{2+}, \mathrm{Na}^{+}, \mathrm{SO}_{4}{ }^{2-}, \mathrm{Cl}^{-}, \mathrm{PO}_{4}{ }^{3-}$ and $\mathrm{Mn}^{3+}$ and water pigments (Fig. 4). 


\section{Discussion}

329 Verification and establishing new ecological indicator values is a key step in standard

330 biomonitoring procedure (Szczepocka \& Żelazna-Wieczorek 2018). To specify ecological

331 indicator values or establish new ones we have determined characteristic species. For these

332 species we performed analysis of environmental condition of the ecosystem where they were

333 noted, previous published data and co-occurring species.

\section{Planothidium delicatulum (PTDE) (Figs 5. A-E)}

335

336

337

338

339

340

341

342

343

344

345

346

347

348

349

350

351

352

353

354

355

356

357

358

359

360

361

362

363

Planothidium delicatulum is a euconstant taxon for PE and an accidental taxon for LE. Its mean percentage share in PE was 2\%, and constituted 5\% in D.PESB.

Planothidium delicatulum does not currently have one ecological indicator value (oxygen requirements) according to Van Dam et al. (1994).

This species was more abundant in environments such as D.PESB, which was also characterized by the highest concentration of $\mathrm{Cl}^{-}$(up to $2976 \mathrm{mg} \mathrm{L}^{-1}$ ), elevated electrolytic conductivity, and decreased $\mathrm{K}^{+}$concentration. The $\mathrm{pH}$ of the water in which this species was observed did not exceed 7.

Planothidium delicatulum was mainly recorded in salty and brackish environments with neutral or slightly alkaline conditions (Campeau, Pienitz \& Héquette 1999; Gell et al. 2005; Caballero et al. 2013; Yamamoto, Chiba \& Tuji 2017; Van de Vijver, Wetzel \& Ector 2018).

Based on our findings, we suggest changing the following ecological indicator values in the Van Dam et al. (1994) classification for P. delicatulum:

- pH requirements: 3 (neutrophilic) (changing from 5 to 3);

- salinity: 5 (brackish-marine) (changing from 4 to 5).

\section{Chamaepinnularia krookiformis (CHKF) (Figs 5. F-I) and Chamaepinnularia plinskii}

\section{(CHPL) (Figs 5. J-M)}

In 2016 Chamaepinnularia krookiformis was divided into two separate taxa: C. krookiformis and C. plinskii (Żelazna-Wieczorek \& Olszyński 2016). Both species were very often recorded together in the same ecosystem. However, the publications which identified C. krookiformis often do not provide appropriate photographic documentation or photos of individual specimens (Witkowski 1994; Bąk, Witkowski, Lange-Bertalot 2006; Wojtal 2008; Peszek et al. 2015). Currently available documentation is insufficient to determine whether $C$. krookiformis and $C$. plinskii are both present simultaneously in a given environment or whether just one of these species exists.

Chamaepinnularia krookiformis is an accessory taxon for PE (a constant taxon for D.PEDB), $C$. plinskii is a constant taxon for PE (a euconstant taxon for D.PEDB). The mean share of $C$.

krookiformis was $1.6 \%$ in all PE samples, $4 \%$ in D.PEDB; for C. plinskii, this amounted to $2.7 \%$ in PE, 6\% in D.PEDB. 
364 Currently, C. krookiformis lacks three assigned ecological indicator values. For PE, it constitutes

365

366

367

368

369

370

371

372

373

374

375

376

377

378

379

380

381

382

383

384

385

386

387

388

389

390

391

392

393

394

395

396

397

398

399

400

401

$6 \%$ of the unknown group in nitrogen uptake, $6 \%$ in oxygen requirements and $6 \%$ in trophic state (respectively for D.PEDB: 16\%, 16\% and 15\%). C. plinskii has no assigned ecological indicator values and represents $26 \%$ of the unknown group for $\mathrm{pH}$ requirements, $19 \%$ for salinity, $12 \%$ for nitrogen uptake, $10 \%$ for oxygen requirements, $14 \%$ for saprobity, $11 \%$ for trophic state and $10 \%$ for moisture (respectively for D.PEDB: $60 \%, 25 \%, 24 \%, 23 \%, 32 \%, 23 \%$ and $28 \%$ ).

The conditions of the environments in which both species have been recorded indicate that they are class 3 with regard to $\mathrm{pH}$ range (neutrophilic). Both species were the most abundant in locations subjected to periodic drying and characterised by high concentrations of chloride ions (up to $1006 \mathrm{mg} \mathrm{L}^{-1}$ ) indicating a brackish environment (Żelazna-Wieczorek, Olszyński \& Nowicka-Krawczyk 2015).

On the basis of our findings and those of previous studies (Krammer \& Lange-Bertalot 1986; Krammer 1992; Witkowski 1994; Bąk, Witkowski \& Lange-Bertalot 2006; Wojtal 2009; Peszek et al. 2015; Żelazna-Wieczorek \& Olszyński 2016), according to Van Dam et al (1994) ecological indicator system we propose: established ecological indicator values for Chamaepinnularia plinskii

- $\mathrm{pH}$ requirements: 3 (neutrophilic);

- salinity: 4 (mesohalobous);

- trophic state: 5 (eutrophic);

- moisture aerophily: 4 (aerophilic);

- saprobity: 4 ( $\alpha$-meso-polysabrobe);

for C. krookiformis

- trophic state: 5 (eutrophic);

and the following changes for Chamaepinnularia krookiformis

- salinity: from 3 to 4 (mesohalobous);

- moisture aerophily: from 3 to 4 (aerophilic);

- saprobity: from 2 to 4 ( $\beta$-mesosaprobe to $\alpha$-meso-polysabrobe). Due to the specific conditions and locations of the studied objects, they were exposed to large fluctuations in the inflow of organic matter, mainly from runoff from arable fields and pollution caused by animal grazing. These impurities were manifested as elevated concentrations of $\mathrm{K}^{+}$ions. Therefore, our results suggest that classifying C. krookiformis as an oligosaprobe is inappropriate. Further tests are needed to determine the optimum occurrence of these species in areas subjected to organic matter loads.

\section{Nitzschia liebethruthii (NLBT) (Figs 5. N-Q)}

Nitzschia liebethruthii is a euconstant taxon for PE. Its means percentage share was $4 \%$ in the PE samples, and $10 \%$ in the D.PEDB samples. It was most numerous in the sample from November 2013 (19\%). This species has two specific ecological indicator values. The ecological indicator value analysis for PE found $N$. liebethruthii to represent $17 \%$ of the unknown group in nitrogen 
402 uptake, $16 \%$ in oxygen requirements, $18 \%$ in saprobity, $17 \%$ in trophic state and $21 \%$ in

403 moisture (respectively for D.PEDB: 37\%, 37\%, 43\%, 36\% and 49\%).

404 Nitzschia liebethruthii occurred in environments subjected to periodic drying with a $\mathrm{pH}$ close to

4057 and high concentration of chloride ions.

406 This species was noted in environments with increased salinity, electrolytic conductivity and

407 high $\mathrm{pH}$ value (Rumrich, Lange-Bertalot \& Rumrich 2000; Witkowski, Lange-Bertalot \&

408 Metzeltin 2000; Lange-Bertalot et al. 2017; Földi et al. 2018).

409 We propose established new ecological indicator values according to Van Dam et al. (1994)

410 assigned to N.liebethruthii:

411 - trophic state: 5 (eutrophic);

412 - moisture aerophily: 4 (aerophilic);

413 and following changes:

414 - pH requirements: from 5 to 3 (alkalibiontic to neutrophilic);

415 - saprobity: from 2 to 4 ( $\beta$-mesosaprobe to $\alpha$-meso-polysabrobe).

416

417

418

419

420

421

422

423

424

425

426

427

428

429

430

431

432

433

434

435

436

437

438

439

440

\section{Craticula buderi (CRBU) (Figs 5. R-U)}

Craticula buderi is a euconstant taxon for PE and an accidental taxon for LE. Its mean percentage share was $4 \%$ in all samples for PE, and $12 \%$ for D.PEPB. This species has no recorded ecological indicator values. The ecological indicator value analysis for the PE found $C$. buderi to constitute $19 \%$ of the unknown group in $\mathrm{pH}$ requirements, $28 \%$ in salinity, $16 \%$ in nitrogen uptake, $16 \%$ in oxygen requirements, $16 \%$ in saprobity, $19 \%$ in trophic state and $15 \%$ in moisture (respectively for D.PEPB: 53\%, 73\%, 46\%, 46\%, 46\%, 54\% and 41\%).

Although Craticula buderi was classified into group B (PCA), it was found to be most abundant in environments with an elevated concentration of $\mathrm{Cl}^{-}$ions, ranging from 685 to $1090 \mathrm{mg} \mathrm{L}^{-1}$, (all samples from D.PEPB and one sample from D .PEDB in which the concentration of chloride ions was $1006 \mathrm{mg} \mathrm{L}^{-1}$ ). However, relative abundance was lower in the D.PEPB sample, which was characterised by a chloride ion content of over $1500 \mathrm{mg} \mathrm{L}^{-1}$. Interestingly. the concentration of $\mathrm{K}^{+}$ions exceeded $100 \mathrm{mg} \mathrm{L}^{-1}$ at $\mathrm{Cl}^{-}$concentrations below $1500 \mathrm{mg} \mathrm{L}^{-1}$; therefore, it is possible that the decline of this species could be related to the concentration of $\mathrm{K}^{+}$ions alone. Our observations indicate that the population of $C$. buderi from D.PEPB favours a concentration of chloride ions from 500 to $1006 \mathrm{mg} \mathrm{L}^{-1}$ which coincides with a $\mathrm{K}^{+}$ions concentration from 50 to $70 \mathrm{mg} \mathrm{L}^{-1}$.

Craticula buderi is widespread throughout the world and recognized as cosmopolitan (Rumrich, Lange-Bertalot \& Rumrich 2000; Lange-Bertalot 2001; Bahls 2009; Soltanpour-Gargari, Lodenius \& Hinz 2011; Żelazna-Wieczorek 2011; Cichoń 2016). This species was found to be dominant in environments characterised by increased electrolytic conductivity and alkaline water (Holmes \& Taylor 2015). Holmes and Taylor (2015) place C. buderi in the Bad water quality class. Their recorded values of diatom indices indicate that the environment was eutrophic. We therefore propose the following classes of ecological indicator values according to Van Dam et al. (1994) for Craticula buderi:

PeerJ reviewing PDF | (2019:05:37496:2:0:NEW 22 Oct 2019) 
441 - pH requirements: 4 (alkaliphilic);

442 - trophic state: 5 (eutrophic);

443 - salinity: 4 (mesohalobous);

444 - moisture aerophily: 3 (aquatic to aerophilic);

445 and following change:

446 - sabrobity: from 2 to 4 ( $\beta$-mesosaprobe to $\alpha$-meso-polysabrobe).

447 Navicula cincta (NCCA) (Figs 5. V-Z)

448 Navicula cincta is a euconstant taxon for PE, a constant taxon for LE and an accessory taxon for 449 BO. The mean percentage share of this species for PE is 3\%, of which 7\% was found in D.PEPB 450 samples.

451 Currently this species has been assigned two ecological indicator values. The ecological 452 indicator values analysis for the PE found $N$. cincta to constitute $24 \%$ of the unknown group in $453 \mathrm{pH}$ requirements, $13 \%$ in nitrogen uptake, 12\% in oxygen requirements, $13 \%$ in saprobity, and $45412 \%$ in moisture (respectively for D.PEPB: $28 \%, 25 \%, 25 \%, 26 \%$ and $23 \%$ ).

455 An analysis of the physical and chemical data and the variability of occurrence did not show any 456 clear relationships between environmental parameters and the percentage share of Navicula 457 cincta in the tested samples. This lack of dependence is also confirmed by the PCA analysis.

458 Navicula cincta has been recorded in various types of ecosystems, although mainly in eutrophic 459 ones with high conductivity. It also tolerates elevated levels of organic matter. This species was 460 also observed in habitats subjected to periodic drying (Lange-Bertalot \& Genkal 1999; Rumrich, 461 Lange-Bertalot \& Rumrich 2000; Witkowski, Lange-Bertalot \& Metzeltin 2000; Lange-Bertalot 462 2001; Żelazna-Wieczorek 2011; Wojtal 2013; Lange-Bertalot, Hofmann \& Werum 2017).

463 However, several new species from the group $N$. cincta s.l. have been described, and it can be 464 assumed that each of these individual species in this group may be associated with narrower 465 optimal ecological conditions (Cantonati et al. 2016).

466 Based on our present findings, and those of previous studies, in our opinion that it is not 467 appropriate to classify Navicula cincta as an oligohalobous species with regard to salinity: it has 468 been recorded in fresh (Żelazna-Wieczorek 2011; Wojtal 2013), brackish (Żelazna-Wieczorek, 469 Olszyński \& Nowicka-Krawczyk 2015; Żurek et al. 2018) and salt waters (Witkowski, Lange470 Bertalot \& Metzeltin 2000). We propose the following ecological indicator value according to 471 Van Dam et al. (1994) for Navicula cincta s.l.:

472 - moisture aerophily: 3 (aquatic to aerophilic).

473 Shade Plot analysis found that the presence of $N$. cincta s.l. can falsely indicate high similarity 474 between samples from different environments, thus distorting the results of any environmental 475 analysis. Therefore, with regard to the unclear taxonomic status of Navicula cincta s.1. and the 476 current lack of knowledge regarding its activities, we recommend this taxon be excluded from 477 the biological assessment of surface water quality.

478 Planothidium frequentissimum (PLFQ) (Figs 5. AA-FF) 
479 Planothidium frequentissimum is a euconstant taxon for PE and LE. The mean percentage of this 480 species for PE is $2.7 \%$, of which $5 \%$ was found in D.PEPB samples. It was most numerous in the 481 D.PEDB.301113 sample (19\%). The species has currently six established ecological indicator 482 values. The ecological indicator values analysis for PE found P. frequentissimum to constitute $48312 \%$ of the unknown group in moisture aerophily (for D.PEPB 14\% and D.PESB: 20\%).

484 No relationship was observed between percentage share of Planothidium frequentissimum and 485 the changes in chemical and physical parameters in the tested samples. This lack of relationship 486 was confirmed by PCA analysis.

487 Planothidium frequentissimum is an eurytopic species that occurs globally in a variety of habitat 488 types, from natural springs to rivers in urban areas with high levels of pollution. Its value as an 489 indicator is low, as confirmed by the Shade Plot analysis, which found it to significantly affect 490 the degree of similarity observed between samples from different environments (Siver, et al. 491 2005; Levkov et al. 2007; Żelazna-Wieczorek 2011; Kulikovskiy, Lange-Bertalot \& Kuznestova 492 2015; Szczepocka, Nowicka-Krawczyk \& Kruk 2018).

493 Recently P. frequentissimum was divided into several different species. In studied samples we 494 observe several species which belong to P. frequentissimum s. 1. (Fig. 5. AA-FF) (Wetzel et al. 495 2019). A light microscope (LM) is still used to identify species in ecological research and 496 biological assessment of aquatic ecosystems. Due to the likeness of the basic morphological 497 features of the newly described species observed in LM, especially in the case of $P$.

498 frequentissimum s.s. and $P$. straubianum, distinguishing them will be difficult or limited, which 499 may lead to errors in the assessment. We therefore recommend that $P$. frequentissimum s. 1 . be 500 excluded from the biological assessment of surface water quality.

501 Cyclostephanos invisitatus (CINV) (Figs 5. GG-JJ)

502 Cyclostephanos invisitatus is a euconstant taxon for LE. Its percentage share for LE was $4.8 \%$. 503 Cyclostephanos invisitatus currently has two ecological indicator values assigned. The ecological 504 indicator values analysis for LE found it to constitute $24 \%$ of the unknown group in $\mathrm{pH}$

505 requirements, $17 \%$ in nitrogen uptake, $18 \%$ in oxygen requirements, $19 \%$ in saprobity, and $20 \%$ 506 in moisture.

507 Cyclostephanos invisitatus occurs in diverse environments, however, it is most frequently 508 reported in aquatic ecosystems subjected to high human impact, alkaline and high conductivity 509 (Reavie \& Smol 1998; Yang et al. 2005; Wojtal \& Kwandrans, 2006; Kiss et al. 2012; Houk, 510 Klee \& Tanaka 2014; Reavie \& Kireta 2015; Olszyński \& Żelazna-Wieczorek 2018).

511 We therefore propose that the following classes of ecological indicator values according to Van 512 Dam et al. (1994) be established for Cyclostephanos invisitatus:

513 - pH requirements: 4 (alkaliphilic);

514 - moisture aerophily: 1 (aquatic).

\section{Navicula moskalii (NMOK) (Figs 5. KK-NN)}


516 Navicula moskalii is an accessory taxon for LE. Its mean percentage share for LE was $1.5 \%$. Its 517 incidence was greatest in sample D.LEP1.250315 (26\%).

518 Navicula moskalii has no assigned ecological indicator values. The ecological indicator value 519 analysis for LE found it to constitute 5\% of the unknown group in $\mathrm{pH}$ requirements, $7 \%$ in

520 salinity, $5 \%$ in nitrogen uptake, $5 \%$ in oxygen requirements, $5 \%$ in saprobity, $6 \%$ in trophic state 521 and 5\% in moisture. The greatest occurrence of $N$. moskalii was observed in samples with the 522 highest concentrations of $\mathrm{Ca}^{2+}\left(143.6 \mathrm{mg} \mathrm{L}^{-1}\right), \mathrm{HCO}^{3-}\left(338.6 \mathrm{mg} \mathrm{L}^{-1}\right), \mathrm{SO}_{4}^{2-}\left(146.9 \mathrm{mg} \mathrm{L}^{-1}\right)$ and 523 with high $\mathrm{Mg}^{2+}$ content.

524 Navicula moskalii was observed in a number of ecosystems (Metzeltin \& Witkowski 1996;

525 Lange-Bertalot 2001; Żelazna-Wieczorek 2011; Noga et al. 2016; Lange-Bertalot et al. 2017), 526 particularly in eutrophic waters with an elevated level of $\mathrm{Ca}^{2+}$ and $\mathrm{HCO}^{3-}$ ions. Żelazna-

527 Wieczorek (2011) report a significant number of $N$. moskalii in springs with high levels of 528 eutrophication, however with $\mathrm{Ca}^{2+}, \mathrm{SO}_{4}{ }^{2-}, \mathrm{HCO}^{3-}$ and $\mathrm{Mg}^{2+}$ concentrations lower than those in 529 the LE samples.

530 We therefore propose that the following classes of ecological indicator values according to Van

531 Dam et al. (1994) be established for Navicula moskalii:

532 - pH requirements: 4 (alkaliphilic);

533 - salinity: 2 (oligohalobous);

534 - trophic state: 7 (indifferent).

\section{Stephanodiscus binatus (SBNT) (Figs 5. OO-RR)}

536 Stephanodiscus binatus is a euconstant taxon for LE. Its percentage share for LE was 4.3\%.

537 Stephanodiscus binatus has no recorded ecological indicator values. The ecological indicator

538 value analysis for LE found it to constitute $25 \%$ of the unknown group in pH requirements, $47 \%$

539 in salinity, $18 \%$ in nitrogen uptake, $18 \%$ in oxygen requirements, $20 \%$ in saprobity, $29 \%$ in

540 trophic state and $21 \%$ in moisture.

541 The largest percentage share of Stephanodiscus binatus was recorded in the spring months and

542 the lowest in autumn. Its abundance was found to be elevated in December 2014 and 2015; the

543 same samples demonstrated the highest concentrations of $\mathrm{Ca}^{2+}, \mathrm{Mg}^{2+}$ and the highest $\mathrm{pH}$ (above

$5448)$.

545 Stephanodiscus binatus has been recorded in various water ecosystems ranging from

546 oligotrophic to eutrophic; however, all are characterised by elevated $\mathrm{pH}$ value (Stoermer \&

547 Håkansson 1984; Håkansson \& Kling 1990; Houk, Klee \& Tanaka 2014; Olszyński \& Żelazna-

548 Wieczorek 2018).

549 We therefore propose that the following classes of ecological indicator values according to Van

550 Dam et al. (1994) be established for Stephanodiscus binatus:

551 - pH requirements: 4 (alkaliphilic);

552 - salinity: 2 (oligohalobous);

553 Stephanodiscus parvus (SPAV) (Figs 5. SS-VV) 
554 Stephanodiscus parvus is a euconstant taxon for LE and an accidental taxon for PE. Its

555

556

557

558

559

560

561

562

563

564

565

566

567

568

569

570

571

572

573

574

575

576

577

578

579

580

581

582

583

584

585

586

587

588

589

590

591 percentage share for LE was $2.4 \%$. It was most abundant in the D.LEP3.260714 sample (22\%). This species has three assigned ecological indicator values. The ecological indicator values analysis for LE found the taxon to constitute $9 \%$ of the unknown group in nitrogen uptake, $9 \%$ in oxygen requirements, $10 \%$ in saprobity, and $10 \%$ in moisture.

Stephanodiscus parvus is noted mainly in eutrophic hypereutrophic ecosystems with elevated electrolytic conductivity. It is also a good indicator of waters with a strong anthropogenic impact (Reavie \& Smol 1998; Reavie \& Kireta, 2015; Olszyński \& Żelazna-Wieczorek 2018; Reavie \& Cai 2019).

Based on our findings and literature data, we propose the following change in ecological indicator values according to Van Dam et al. (1994) for Stephanodiscus parvus: - pH requirements: from 5 to 4 (alkalibiontic to alkaliphilic).

\section{Diatoma moniliformis (DMOF) (Figs 5. WW-AAA)}

Diatoma moniliformis is a euconstant taxon for BO. Its mean percentage share for BO was $3.9 \%$. It currently has no assigned ecological indicator values. According to the ecological indicator values analysis for $\mathrm{BO}$, this taxon constituted $10 \%$ of the unknown group in $\mathrm{pH}$ requirements, $11 \%$ in salinity, $8 \%$ in nitrogen uptake, $8 \%$ in oxygen requirements, $9 \%$ in saprobity, $9 \%$ in trophic state and $8 \%$ in moisture.

Diatoma moniliformis was found in $87.5 \%$ of samples from BO. Interestingly, it constituted $28 \%$ of the share in one sample from December 2016 (D.BOZB.091216); however, its share was below $2 \%$ in the previous season, and was not higher than $1-2 \%$ in the other samples from December 2016. The chemical and physical characteristics of D.BOZB.091216 did not differ significantly from those of the other samples.

This species is also found in fresh and salt water, as well as the Baltic and arctic areas with high conductivity (Potapova \& Snoeijs 1997; Rumrich, Lange-Bertalot \& Rumrich 2000; Levkov et al. 2007; Pniewski \& Sylwestrzak 2018).

One of the factors that influences the abundance of $D$. moniliformis is the water temperature. Studies indicate that temperatures above $10-15^{\circ} \mathrm{C}$ (Potapova \& Snoeijs 1997; Pniewski \& Sylwestrzak 2018) are associated with population growth. However, populations have been observed in freshwater streams and lakes in arctic areas, in which the temperature of the water is below $10^{\circ} \mathrm{C}$ (Antoniades Douglas \& Smol 2005). Population growth was also observed at $4.7^{\circ} \mathrm{C}$ in sample D.BOZB.091216; therefore, low temperature may have an influence on the abundance of this species.

\section{Encyonopsis subminuta (ESUM) (Figs 5. BBB-GGG)}

Encyonopsis subminuta is a euconstant taxon in BO, where its mean percentage share was $4.1 \%$. Presently, E. subminuta has been assigned five ecological indicator values. Ecological indicator values analysis for $\mathrm{BO}$ found it to constitute $7 \%$ of the unknown group in nitrogen uptake and $8 \%$ in moisture. 
592 Encyonopsis subminuta was found to be most abundant in sample D.BOZB.041115. The sample 593 was also characterised by an elevated concentration of $\mathrm{Fe}^{2+/ 3+}$ ions and the lowest $\mathrm{pH}$ value. In

594 subsequent samples, when the concentration of Fe ions dropped, the abundance of E. subminuta 595 also decreased.

596 Encyonopsis subminuta is regarded as a cosmopolitan taxon, occurring in the temperate and 597 boreal zone. It is most abundant in oligo- to mesotrophic waters with electrolytic conductivity 598 between 190-250 $\mu \mathrm{S} \mathrm{cm}$ c $^{-1}$ (Krammer 1997; Noga et al. 2014; Novais et al. 2014; Feret, Bouchez 599 \& Rimet 2017).

600 Encyonopsis subminuta may be sensitive to the concentration of Fe ions; however, the increase 601 of these ions is associated with a drop in $\mathrm{pH}$. Our research confirms that the optimal $\mathrm{pH}$ for 602 population size is close to 7.

\section{Mastogloia smithii (MSMI) (Figs 5. HHH-MMM)}

604 Mastogloia smithii is a euconstant taxon for BO. Its mean percentage share for BO was $6.3 \%$. it 605 was found in greatest numbers in D.BOZB.300615 (22\%) and D.BOZB.261016 (15\%).

606 Mastogloia smithii has been assigned four ecological indicator values. The ecological indicator

607 values analysis for the BO found this species to constitute $13 \%$ of the unknown group in nitrogen 608 uptake, $14 \%$ in oxygen requirements and $15 \%$ in trophic state.

609 The environment in BO regarding salinity was classified according to Vam Dam et al. (1994) as 610 oligohalobus (43\% species); however, $7 \%$ of the mesohalobous species were represented by one 611 species: Mastogloia smithii.

612 This species is recorded in fresh, brackish and salt water (Witkowski, Lange-Bertalot \& Metzeltin

613 2000; Busse \& Snoeijs 2003; Weckström \& Juggins 2005; Martinzes-Goss \& Evangelista 2011;

614 Lange-Bertalot et al. 2017). Its presence in environments with varying degrees of salinity may

615 suggest that this does not have an significant influence on population size.

616 Based on our present findings and literature data, we propose the following change in the

617 ecological indicator values according to Van Dam et al. (1994) for Mastogloia smithii:

618 - salinity: from 4 to 3 (mesohalobous to halophilic).

\section{Nitzschia dissipata var. media (NDME) (Figs 5. NNN-QQQ)}

620 Nitzschia dissipata var. media is a euconstant taxon for BO. Its mean percentage share for BO 621 was 3.8\%, and the highest proportion (20\%) was found in D.BOZB.041115. N. dissipata var.

622 media has been assigned two ecological indicator values. Ecological indicator values analysis for 623 BO found it to constitute $9 \%$ of the unknown group in nitrogen uptake, $10 \%$ in oxygen

624 requirements, $11 \%$ in saprobity, $11 \%$ in trophic state and $9 \%$ in moisture.

625 The increase in occurrence of $N$. dissipata var. media is associated with an increase in the level 626 of $\mathrm{Fe}^{2+} / 3+$, similar to Encyonopsis subminuta. In addition, it was found in the ecosystem, i.e. BO, 627 with the lowest concentrations of ions indicative of the presence of organic pollutants in the 628 environment, such as $\mathrm{K}^{+}$and $\mathrm{NH}_{4}{ }^{+}$. 
629 Although Nitzschia dissipata var. media is found sporadically, it is commonly found in oligo- to 630 mesotrophic waters with a pH between 7 and 8 (Van der Vijver, Frenot \& Beyens 2002;

631 Antoniades, Douglas \& Smol 2005; Żelazna-Wieczorek 2011; Lange-Bertalot, Hofmann \& 632 Werum 2017).

633 Based on our findings and literature data, we propose the following ecological indicator values 634 according to Van Dam et al. (1994) for Nitzschia dissipata var. media:

635 - saprobity: 2 ( $\beta$-mesosaprobe)

636

637

638

639

640

641

642

643

644

645

646

647

648

649

650

651

\section{2}

653

654

655

656

657

658

659

660

661

662

663

664

665

666

\section{Pantocsekiella pseudocomensis (PPCS) (Figs 5. RRR-XXX)}

Pantocsekiella pseudocomensis is a euconstant taxon for $\mathrm{BO}$. Its mean percentage share for $\mathrm{BO}$ was 4.4\%. It was most abundant in D.BOZB.250315 (9\%) and in D.BOZB.220616 (10\%). P. pseudocomensis has not been assigned any ecological indicator values according to Van Dam et al. (1994). The ecological indicator values analysis for BO found it to represent $22 \%$ of the unknown group in $\mathrm{pH}$ requirements, $25 \%$ in salinity, $10 \%$ in nitrogen uptake, $11 \%$ in oxygen requirements, $18 \%$ in saprobity, $12 \%$ in trophic state and $13 \%$ in moisture.

The greatest amount of $P$. pseudocomensis was found in samples characterised by the highest levels of ammonium ions. Its percentage share was lowest in samples with the lowest water temperature, apart from D.BOZB.250315.

Currently, Pantocsekiella pseudocomensis is assigned to the P. comensis complex, with $P$. comensis and $P$. costei. In our opinion that assigning ecological indicator values for particular species of the $P$. comensis complex is unjustified at the current state of knowledge, and that all species within the complex should be assigned the same provisional ecological indicator values until their individual properties are better understood (Houk, Klee \& Tanaka 2010; Kistenich et al. 2014; Duleba et al. 2015).

\section{Conclusions}

The water ecosystems created in the post-mining areas create a complex of conditions that are not found in other natural ecosystems, and the benthic diatom species present in such environments are very often present in higher numbers than in other habitats. The specific hydrogeological conditions prevailing in the post-production reservoirs provide a unique opportunity to observe interspecies differences and intra-species variability, allowing for the verification or isolation of new taxa and a greater insight into their autecology (Żelazna-Wieczorek \& Olszyński 2016; Olszyński \& Żelazna-Wieczorek 2018).

The identification of species characteristic of the studied ecosystems may foster further growth of ecological research and increase the reliability of surface water quality assessment, as such knowledge is needed to verify their ecological indicator values, and hence calculate diatoms indices with greater accuracy.

Ecological indicator values as set out by Van Dam et al. (1994) are utilized in many ecological works describing the ecological conditions of the studied ecosystems. These ecological indicator values form the basis for calculating diatoms indices describing the ecological state of surface 
667 waters. It is therefore necessary to constantly update and establish new ecological indicator 668 values for particular diatom species.

669 Many authors who describe new species, or encounter existing species in new ecosystems, 670 regularly propose updates for individual ecological indicator values. However, these findings, 671 may not be introduced and updated in the OMNIDIA program for a number of years. The 672 OMNIDIA system is used by state institutions in many countries around the world to assess 673 surface water quality (Campeau, Pienitz \& Héquette 1999; Rumrich, Lange-Bertalot \& Rumrich 674 2000; Witkowski, Lange-Bertalot \& Metzeltin 2000; Gell et al. 2005; Potapova \& Ponader 675 2008; Wojtal \& Sobczyk 2012; Caballero et al. 2013; Żelazna-Wieczorek \& Olszyński 2015; 676 Yamamoto, Chiba \& Tuji 2017; Lange-Bertalot, Hofmann \& Werum 2017; Földi et al. 2018; 677 Van de Vijver, Wetzel \& Ector 2018). Clearly, if these assessments are based on incomplete or 678 outdated data, assessments of aquatic environments may be fraught with error.

679 The present study used three principles to identify proposed changes in the classification of 680 ecological indicator values for characteristic species according to the Van Dam et al. (1994) 681 system, or to establish new values which were previously absent: the analysis of environmental 682 conditions prevailing in the studied ecosystems, the analysis of relevant literature data, and 683 references to the ecological indicator values of other species (Table 4). This mode of research 684 can serve as a model for updating databases used to assess surface water quality.

\section{References}

686

687

688

689

690

691

692

693

694

695

696

697

698

699

700

701

702

703

704

705

706

Antoniades D., Douglas M.S.V. \& Smol J.P. 2005. Benthic diatom autecology and inference model development from the Canadian High Arctic Archipelago. Journal of Phycology 41: 30-45 DOI: 10.1111/j.1529-8817.2005.04049.x.

Bahls L.L. 2009. A checklist of diatoms from inland waters of the northwestern United States. Proceedings of The Academy of Natural Sciences of Philadelphia 158: 1-35 DOI: 10.1635/053.158.0101.

Bąk M., Witkowski A. \& Lange-Bertalot H. 2006. Diatom flora diversity in the strongly eutrophicated and $\beta$-mesosaprobic waters of the Szczecin Lagoon, NW Poland, southern Baltic Sea. - In: Ognjanova-Rumenova N. \& Manoylov K., eds. Advances in Phycological Studies, Festschrift in Honour of Professor Dobrina TeminskovaTopalova. Sofia - Moscow: Pensoft Publishers \& University Publishing House, 293317.

Busse S. \& Snoeijs P. 2003. Gradient responses of diatom communities in the Bothnian Sea (northern Baltic Sea), with emphasis on responses to water movement. Phycologia 42(5): 451-464 DOI: 10.2216/i0031-8884-42-5-451.1.

Caballero M., Rodríguez A., Vilaclara G., Ortega B., Roy P. \& Lozano S. 2013. Hydrochemistry, ostracods and diatoms in a deep, tropical, crater lake in Western Mexico. Journal of Limnology 72(3): 512-523 DOI: 10.4081/jlimnol.2013.e42.

Campeau S., Pienitz R. \& Héquette A. 1999. Diatoms from the Beaufort Sea coast, southern Arctic Ocean (Canada). In: Lange-Bertalot H. \& Kociolek P., eds. Bibliotheca Diatomologica Vol. 42. Berlin, Stuttgart: J. CRAMER 244 p.

PeerJ reviewing PDF | (2019:05:37496:2:0:NEW 22 Oct 2019) 
707

708

709

710

711

712

713

714

715

716

717

718

719

720

721

722

723

724

725

726

727

728

729

730

731

732

733

734

735

736

737

738

739

740

741

742

743

744

745

Cantonati M., Angeli N. Spitale D. \& Lange-Bertalot H. 2016. A new Navicula (Bacillariophyta) species from low-elevation carbonate springs affected by anthropogenic disturbance. Fottea, Olomouc 16(2): 255-265 DOI: 10.5507/fot.2016.013.

Cichoń S. 2016. Craticula buderi (Bacillariophyceae) in Poland. Polish Botanical Journal 61(2): 301-305 DOI: 10.1515/pbj-2016-0024.

Clarke K.R. \& Gorley, R.N. 2015. PRIMER v7: User Manual/Tutorial. Devon, United: Kingdom: PRIMER-E Ltd 296 pp.

de Haan H., Van Liere L., Klapwijk Sj.P. \& Van Donk E. 1993. The structure and function of fen lakes in relation to water table management in The Netherlands. Hydrobiologia 265: 155-177 http://dx.doi.org/10.1007/BF00007266.

Duleba M., Kiss K.T., Földi A., Kovács J., Borojević K.K., Molnár L.F., Plenković-Moraj A., Pohner Z., Solak C.N., Tóth B. \& Ács E. 2015. Morphological and genetic variability of assemblages of Cyclotella ocellata Pantocsek/C. comensis Grunow complex (Bacillariophyta, Thalassiosirales), Diatom Research 30(4): 283-306 DOI: 10.1080/0269249X.2015.1101402.

European Union. 2000. Directive 2000/60/EC of the European Parliament and of the Council of 23 October 2000 establishing a framework for community action in the field of water policy. Official Journal of the European Communities L327, 1-73.

Feret L., Bouchez A. \& Rimet F. 2017. Benthic diatom communities in high altitude lakes: a large scale study in the French Alps. Annales de Limnologie - International Journal of Limnology 53: 411-423 DOI: 10.1051/limn/2017025.

Ferreira da Silva E., Almeida A.F.P., Nunes M.L., Luís A.T., Borg F., Hedlund M., Marques de Sá C., Patinha C. \& Teixeira P. 2009. Heavy metal pollution downstream the abandoned Coval da Mó mine (Portugal) and associated effects on epilithic diatom communities. Science of the Total Environment 407: 5620-5636 doi:10.1016/j.scitotenv.2009.06.047.

Földi A., Ács É., Grigorszky I., Ector L., Wetzel C.E., Várbíró G., Kiss K.T, Dobosy P., Trábert Z., Borsodi A.K. \& Duleba M. 2018. Unexpected consequences of bombing. Community level response of epiphytic diatoms to environmental stress in a saline bomb crater pond area. PLoS ONE 13(10): e0205343 https://doi.org/10.1371/journal.pone.0205343.

Gabryś-Godlewska A., Gruszecki J., Kochanowska J., Kozula R., Pasieczna A. \& TomassiMorawiec H. 2004. Arkusz Turek (550). In: Sikorska-Maykowska M., Zdanowski A. \& Gabryś-Godlewska A., eds. Objaśnienia do mapy geośrodowiskowej Polski 1:50 000. Warszawa: Państwowy Instytut Geologiczny. Opracowanie Zamówione Przez Ministra Środowiska. p 30.

Gadomska W., Kaźmierczak J., Merdzińska M., Zielińska B., Wiśniewska-Zientara G., Gajda M., Opas Z., Cieślak J., Kończak D., Kujawa S., Lukasiewicz J., Zielińska-Adasiak S., Ratajczyk G., Michalska R. \& Sobczak D. 2007. Raport o stanie gminy Brudzew lata 2002-2006. Urząd Gminy Brudzew. Brudzew. p. 15. 
746 Gell P.A., Bulpin S., Wallbrink P., Hancock G. \& Bickford S. 2005. Tareena Billabong - a

747

748

749

750

751

752

753

754

755

756

757

758

759

760

761

762

763

764

765

766

767

768

769

770

771

772

773

774

775

776

777

778

779

780

781

782

783

784 palaeolimnological history of an ever-changing wetland, Chowilla Floodplain, lower Murray-Darling Basin, Australia. Marine and Freshwater Research 56: 441-456 DOI: 10.1071/MF04107.

Harding W.R. \& Taylor J.C. 2014. Diatoms as indicators of historical water quality: A comparison of samples taken in the Wemmershoek catchment (Western Province, South Africa) in 1960 and 2008. Water S.A. 40 (4): 601-606.

Håkansson H. \& Kling H. 1990. The current status of some very small freshwater diatoms of the genera Stephanodiscus and Cyclostephanos. Diatom Research 5: 273-287 DOI:10.1080/0269249X.1990.9705119.

Houk, V., Klee R. \& Tanaka H. 2010. Atlas of freshwater centric diatoms with a brief key and descriptions. Part III. Stephanodiscaceae A. Fottea (Supplement) 10:1-498.

Houk V., Klee R. \& Tanaka H. 2014. Atlas of freshwater centric diatoms with a brief key and descriptions. Part IV. Stephanodiscaceae B. Fottea (Supplement) 14:1-532.

Holmes M. \& Taylor J.C. 2015. Diatoms as water quality indicators in the upper reaches of the Great Fish River, Eastern Cape, South Africa. African Journal of Aquatic Science 1-17 DOI: $10.2989 / 16085914.2015 .1086722$.

Hutorowicz A. \& Pasztalenic A. 2014. Phytoplankton metric of ecological status assessment for polish lakes and its performance along nutrient gradient. Polish Journal of Ecology 62(3): 525-540 DOI:10.3161/104.062.0312.

Kahlert M., Ács E., Almeida S.F.P., Blanco S., Dreßler M., Ector L., Karjalainen S.M., Liess A., Mertens A., van der Wal J., Vilaste S. \& Werner P. 2016. Quality assurance of diatom counts in Europe: towards harmonized datasets. Hydrobiologia 772: 1-14 DOI: 10.1007/s10750-016-2651-8.

Kasztelewicz Z. 2011. Assessment of Reclamation Works in Polish Open-pit Lignite Mining. Studia KPZK 142: 440-452.

Kelly M.G., Juggins S., Guthrie R., Pritchard S., Jamieson J., Rippey B., Hirst H. \&Yallop M. 2008. Assessment of ecological status in U.K. rivers using diatoms. Freshwater Biology 53 (2): 403-422 DOI: 10.1111/j.1365-2427.2007.01903.x.

Kiss K.T, Klee R., Ector L. \& Ács É. 2012. Centric diatoms of large rivers and tributaries in Hungary: morphology and biogeographic distribution. Acta Botanica Croatica 71: $311-$ 363 DOI: $10.2478 / \mathrm{v} 10184-011-0067-0$

Kistenich S., Dreßler M., Zimmermann J., Hübener T., Bastrop R. \& Jahn R. 2014. An investigation into the morphology and genetics of Cyclotella comensis and closely related taxa. Diatom Research 29(4): 423-440 DOI: 10.1080/0269249X.2014.922125.

Kolada A., Pasztaleniec A., Bielczyńska A. \& Soszka H. 2016. Phytoplankton, macrophytes and benthic diatoms in lake classification: consistent, congruent, redundant? Lessons learnt from WFD-compliant monitoring in Poland. Journal of Limnology 59: 44-52 DOI: 10.1016/j.limno.2016.05.003. 
785

786

787

788

789

790

791

792

793

794

795

796

797

798

799

800

801

802

803

804

805

806

807

808

809

810

811

812

813

814

815

816

817

818

819

820

821

822

823

Krammer K. 1992. Pinnularia. Eine Monographie der europäischen Taxa In: Bibliotheca Diatomologica 26. Berlin-Stuttgart: J. Cramer. 353 pp.

Krammer K. 1997. Die cymbelloiden Diatomeen. Eine Monographie der weltweit bekannten Taxa. Teil 2. Encyonema part,. Encyonopsis and Cymbellopsis. In:. Lange-Bertalot H. \& Kociolek P., eds. Bibliotheca Diatomologica Vol. 37. Berlin, Stuttgart: J. CRAMER. 96 pp.

Krammer K. \& Lange-Bertalot H. 1986. Bacillariophyceae. 1. Teil: Naviculaceae In: Ettl H.H, Gerloff J., Heynig H. \& Mollenhauer D., eds. Süsswasserflora von Mitteleuropa, Band 2/1. Jena: Gustav Fisher Verlag. 876 pp.

Krammer K. \& Lange-Bertalot H. 1997. Bacillariophyceae. 1. Teil: Bacillariaceae, Epithemiaceae, Surirellaceae. In: Ettl H.H, Gerloff J., Heynig H. \& Mollenhauer D., eds. Süsswasserflora von Mitteleuropa, Band 2/2. Jena Stuttgart Lübeck Ulm: Gustav Fisher Verlag. 611 pp.

Kulikovskiy M.S., Lange-Bertalot H. \& Kuznetsova I.V. 2015. Lake Baikal: Hotspot of Endemic Diatoms II. In: Lange-Bertalot H., ed. Iconographia Diatomologica Vol. 26. TaxonomyBiogeography-Diversity. Germany: Koeltz Scientific Books. 656 pp.

Lange-Bertalot H. 2001. Navicula sensu stricto. 10 Genera Separated from Navicula sensu lato. Frustulia. In: Lange-Bertalot H., ed. Diatom of Europe Vol. 2. Ruggell:vA.R.G. Gantner Verlag K.G. 526 pp.

Lange-Bertalot H. \& Genkal S.I. 1999. Diatoms from Siberia I. Islands in the Arctic Ocean (Yugorsky-Shar Strait). In: Lange-Bertalot H., ed. Iconographia Diatomologica Vol. 6. Phytogeography-Diversity-Taxonomy. Vaduz: A.R.G. Gantner Verlag K.G. 292 pp.

Lange-Bertalot H., Hofmann G., Werum M. \& Cantonati M. 2017. Freshwater Benthic Diatoms of Central Europe: Over 800 Common Species Used in Ecological Assessment. Koeltz Botanical Books. 942 pp.

Lecointe C., Coste M. \& Prygiel J. 1993. “Omnidia:” a software for taxonomy, calculation of diatom indices and inventories management. Hydrobiologia 269/270: 509-513.

Levkov Z., Krstic S., Metzeltin D. \& Nakov T. 2007. Diatoms of Lakes Prespa and Ohrid. About 500 taxa from ancient lake system. In: Lange-Bertalot H., ed. Inconografia Datomologica Vol. 16. Ruggell: A.R.G. Gantner Verlag K.G. 613 pp.

Luís A.T., Durães, N., Fernandes Pinheiro de Almeida S. \& Ferreira da Silva E. 2016. Integrating geochemical (surface waters, stream sediments) and biological (diatoms) approaches to assess AMD environmental impact in a pyritic mining area: Aljustrel (Alentejo, Portugal). Journal of Environmental Sciences 42: 215-226 http://dx.doi.org/10.1016/j.jes.2015.07.008.

Luís A.T., Teixeira P., Almeida S.F.P., Ector L., \& Matos J.X. \& Ferreira da Silva E.A. 2009. Impact of Acid Mine Drainage (AMD) on Water Quality, Stream Sediments and Periphytic Diatom Communities in the Surrounding Streams of Aljustrel Mining Area (Portugal). Water Air Soil Pollution 200:147-167 DOI: 10.1007/s11270-008-9900-z. 
824 Macioszczyk A. \& Dobrzyński D. 2002. Hydrogeochemia. Wydawnictwo Naukowe PWN.

$825 \quad$ Warszawa. 448 pp.

826 Martinez-Goss M.R. \& Evangelista L.T. 2011. A Contribution to the Taxonomy of Mastogloia

827 (Class Bacillariophyceae) in the Philippines. Philippine Journal of Science 140(1): 7-12.

828 Metzeltin D. \& Witkowski A. 1996. Diatomeen der Bären-Insel. Süßwasser- und marine Arten.

829 In: Lange-Bertalot H., ed. Iconographia Diatomologica. Annotated Diatom

830 Micrographs. Vol 4. Taxonomy. Königstein/Germany: Koeltz Scientific Books 20-21.

831 Noga T., Stanek-Tarkowska J., Pajączek A., Kochman N. \& Peszek Ł. 2014. Ecological

832 assessment of the San River water quality on the area of the San Valley Landscape Park.

833 Journal of Ecological Engineering 15(4): 12-22 DOI: 10.12911/22998993.1125453.

834 Noga T., Stanek-Tarkowska J., Rybek M., Kochaman-Kędziora N., Peszek Ł. \& Pajączek A.

835 2016. Diversity of diatoms in the natural, mid-forest Terebowiec Stream - Bieszczady

836

837

838

839

840

841

842

843

844

845

846

847

848

849

850

851

852

853

854

855

856

857

858

859

860

861

862

863 National Park. Journal of Ecological Engineering 17(4): 232-247 DOI: 10.12911/22998993/64506.

Novais M.H., Morais M.M., Rosado J., Dias L.S, Hoffmann L. \& Ector L. 2014. Diatoms of temporary and permanent watercourses in Southern Europe (Portugal). River Research and Applications 30: 1216-1232 DOI: 10.1002/rra.2818.

Olaczek R. 1963. Zbiorowiska roślinne torfowisk niskich okolic Łęczycy. Unpublished doctoral dissertation, University of Lodz, Poland.

Olszyński R.M. \& Żelazna-Wieczorek J. 2018. Aulacoseira pseudomuzzanensis sp. nov. and other centric diatoms from post iron ore mining reservoirs in Poland. Diatom Research 33(2): 155-185 DOI: 10.1080/0269249X.2018.1509886.

Orlikowski D. \& Szwed L. 2009. Wodny kierunek rekultywacji w KWB „Adamów” SA inwestycją w przyszłość regionu. Górnictwo i Geoinżynieria 33(2): 351-361.

Peszek Ł., Noga T., Stanek-Tarkowska J., Pajączek A., Kochman-Kędziora N., Pieniążek M. 2015. The effect of anthropogenic change in the structure of diatoms and water quality of the Żołynianka and Jagielnia streams. Journal of Ecological Engineering 16(2): 33$51 \mathrm{https} / / /$ doi.org/10.12911/22998993/1856.

Pliński M. 1966. Glony słonego źródła w Pełczyskach pod Ozorkowem. Unpublished master dissertation, University of Lodz, Poland.

Pliński M. 1969. Okrzemki słonego źródła w Pełczyskach pod Ozorkowem. Zesz. Nauk. Ut 2(31): 123-136.

Pliński M. 1971a. Rzadkie i nowe dla flory Polski gatunki glonów z terenów solnisk w okolicach Łęczycy. Zesz. Nauk. UŁ 2(41): 171-184.

Pliński M. 1971b. Gatunki z rodzaju Enteromorpha (Link.) Agardh z terenu solnisk podłęczyckich. Zesz. Nauk. Ut. 2(41): 159-169.

Pliński M. 1971c. System halobow w świetle współczesnych poglądów. Wiad. Ekol. 17(1): 1829.

Pliński M. 1973. Glony solnisk podłęczyckich. The algae of salt marches near Łęczyca, Central Poland. Mon. Botanic.39. 
864 Pniewski F. \& Sylwestrzak Z. 2018. Influence of short periods of increased water temperature on

865

866

867

868

869

870

871

872

873

874

875

876

877

878

879

880

881

882

883

884

885

886

887

888

889

890

891

892

893

894

895

896

897

898

899

900

901 species composition and photosynthetic activity in the Baltic periphyton communities. Biologia 73(11): 1067-1072 https://doi.org/10.2478/s11756-018-0122-6.

Poikane S., Kelly M. \& Cantonati M. 2016. Benthic algal assessment of ecological status in European lakes and rivers: Challenges and opportunities. Science of the Total Environment 568: 603-613 DOI:10,1016/j.scitotenv.2016.02.027.

Potapova M. \& Snoeijs P. 1997. The natural life cycle in wild populations of Diatom moniliformis (Bacillariophyceae) and its disruption in an aberrant environment. Journal of Phycology 33: 924-937 https://doi.org/10.1111/j.0022-3646.1997.00924.x.

Potapova M.G. \& Ponader K.C. 2008. New species and combinations in the diatom genus Sellaphora (Sellaphoraceae) from Southeastern United States. Harvard Papers in Botany 13(1): 171-181 DOI: 10.3100/1043-4534(2008)13[171:NSACIT]2.0.CO;2.

Rakowska B. 1996. The benthic diatom community of a reservoir after the exploration of brow coal in Konin (central Poland). Algological Studies 82: 103-116 http://dx.doi.org/0342-1120/0116-103.

Reavie E.D. \& Cai M. 2019. Consideration of species-specific diatom indicators of anthropogenic stress in the Great Lakes. PLoS ONE 14(5): e0210927 DOI: https://doi.org/10.1371/journal.pone.0210927

Reavie E.D. \& Kireta A.R. 2015. Centric, Araphid and Eunotioid Diatoms of the Coastal Laurentian Great Lakes. In: Lange-Bertalot H. \& Kociolek J.P., eds. Bibliotheca Diatomologica Vol. 62. Stuttgart: J. Cramer Gebr. Borntraeger Verlagsbuchhandlung. $184 \mathrm{pp}$.

Reavie E.D. \& Smol J.P. 1998. Freshwater diatoms from the St. Lawrence river. In: LangeBertalot H. \& Kociolek J.P., eds. Bibliotheca Diatomologica Vol 41. Berlin, Stuttgart: J. Cramer Gebr. Borntraeger Verlagsbuchhandlung, 184 pp.

Rumrich U., Lange-Bertalot H. \& Rumrich, M. 2000. Diatomeen der Anden. Von Venezuela bis Patagonien/Tierra del Fuego. Und zwei weitere Beiträge. In: Lange-Bertalot H., ed. Iconographia Diatomologica Vol. 9. Ruggell: A.R.G. Gantner Verlag K.G. 673 pp.

Sienkiewicz E. \& Gąsiorowski M. 2016. The evolution of a mining lake - From acidity to natural neutralization. Science of the Total Environment 557-558: 343-354 http://dx.doi.org/10.1016/j.scitotenv.2016.03.088.

Siver P.A., Hamilton P.B., Stachura-Suchoples K. \& Kociołek J.P. 2005. The Freshwater Flora of Cape Code, Massachusetts, U.S.A. In: Lange-Bertalot H., eds. Iconographia Diatomologica Vol. 14. Diatoms of North America. Ruggell: A.R.G. Gantner Verlag K.G. 463 pp.

Soltanpour-Gargari A., Lodenius M. \& Hinz F. 2011. Epilithic diatoms (Bacillariophycae) from streams in Ramsar, Iran. Acta Botanica Croatica. 70(2): 167-190 DOI: 10.2478/v10184010-0006-5. 
902 Stoermer E.F. \& Håkansson H. 1984. Stephanodiscus parvus: validation of an enigmatic and

903

904

905

906

907

908

909

910

911

912

913

914

915

916

917

918

919

920

921

922

923

924

925

926

927

928

929

930

931

932

933

934

935

936

937

938

939

940

941

widely misconstrued taxon. Nova Hedwigia 39: 497-511

http://www.jstor.org/stable/3226406.

Szczepocka E., Nowicka-Krawczyk P. \& Kruk A. 2018. Deceptive ecological status of urban streams and rivers - evidence from diatom indices. Ecosphere 9(7):e02310 DOI: $10.1002 /$ ecs 2.2310

Szczepocka E., Szulc B., Szulc K., Rakowska B. \& Żelazna-Wieczorek J. 2014. Diatom indices in the biological assessment of the water quality based on the example of a small lowland river. Oceanological and Hydrobiological Studies 43(3): 265-273 DOI: 10.2478/s13545-014-0141-z

Szczepocka E. \& Żelazna-Wieczorek J. 2018. Diatom biomonitoring - scientific foundations, commonly discussed issues and frequently committed errors. Oceanological and Hydrobiological Studies 47(3): 313-325 DOI: 10.1515/ohs-2018-0030

Thomas E.J. \& John J. 2006. Diatoms and macroinvertebrates as biomonitors of mine-like in Collie, Western Australia. Journal of the Royal Society of Western Australia 89: $109-117$.

Tümpling W. \& Friedrich G. 1999. Methiden der Biologischen Wasseruntersuchung. Jena. Stutgart. Lübeck. Ulm. G. Fischer Verlag 133-153.

Van Dam H., Mertens A. \& Sinkeldam, J. 1994. A coded checklist and ecological indicator values of freshwater diatoms from the Netherlands. Netherlands Journal of Aquatic Ecology 28: 117-133.

Van de Vijver B., Frenot Y. \& Beyens L. 2002. Freshwater diatoms from Ile de la Possession. In: Lange-Bertalot H. \& Kociolek P., eds. Bibliotheca Diatomologica Vol. 46. Stuttgart: J. CRAMER in der Gebr. Borbtraeger Verlagsbuchhandlung $71 \mathrm{p}$.

Van de Vijver B., Wetzel C.E. \& Ector L. 2018. Analysis of the type material of Planothidium delicatulum (Bacillariophyta) with the description of two new Planothidium species from the sub-Antarctic Region. Fottea 18(2): 200-211 DOI: 10.5507/fot.2018.006.

Van Landingham S.L. 1968. Investigation of a diatom population from mine Tailigns in Nye Country, Nevada, U.S.A. Journal of Phycology 4: 306-310.

Weckström K. \& Juggins S. 2005. Coastal diatom-environment relationships from the Gulf of Finland, Baltic Sea. Journal of Phycology 42: 21-35 DOI: 10.1111/j.15298817.2006.00166.x

Witkowski A. 1994. Recent and fossil diatom flora of the Gulf of Gdańsk, Southern Baltic Sea. In: Bibliotheca Diatomologica Vol. 28. Cramer, Berlin, Stuttgart. 313 pp

Witkowski A., Lange-Bertalot H. \& Metzeltin D. 2000. Diatom flora of marine coasts I. In: Lange-Bertalot H., ed. Iconographia Diatomologica. Vol. 7. Diversity-TaxonomyIdentification. Ruggell, Liechtenstein: A.R.G. Gantner Verlag K.G. 419 pp.

Wetzel C.E., Van de Vijver B., Blanco S. \& Ector L. 2019. On some common and new cavumbearing Planothidium (Bacillariophyta) species from freshwater. Fottea 19(1): 50-89 DOI: $10.5507 /$ fot.2018.016

PeerJ reviewing PDF | (2019:05:37496:2:0:NEW 22 Oct 2019) 
942 Wojtal A.Z. 2009. The diatoms of Kobylanka stream near Kraków (Wyżyna Krakowsko943 Częstochowska upland, S Poland). Polish Botanical Journal 54: 129-330.

944 Wojtal A.Z. 2013. Species composition and distribution of diatom assemblages in spring water

945

946

947

948

949

950

951

952

953

954

955

956

957

958

959

960

961

962

963

964

965

966

967

968

969

970

971

972

973

974

975

976

977

978

979

980

981 from various geological formation in Southern Poland. In: Lange-Bertalot H. \& Kociolek P., eds. Bibliotheca Diatomologica Vol. 59. Stuttgart: J. CRAMER in der Gebr. Borbtraeger Verlagsbuchhandlung. 436 p.

Wojtal A.Z. \& Kwandrans J. 2006. Diatoms of the Wyżyna Krakowsko-Częstochowska Upland (S. Poland) - Coscinodiscophyceae (Thalassiositophycidae). Polish Botanical Journal 51: 177-207.

Wojtal A.Z. \& Sobczyk Ł. 2012. The influence of substrates and physicochemical factors on the composition of diatom assemblages in karst springs and their applicability in waterquality assessment. Hydrobiologia 695: 97-108 DOI 10.1007/s10750-012-1203-0.

Yang X-D., Dong X-H., Gao G., Pan H-X. \& Wu J-L. 2005. Relationship Between Surface Sediment Diatoms and Summer Water Quality in Shallow Lakes of the Middle and Lower Reaches of the Yangtze River. Journal of Integrative Plant Biology 4792: 153164 https://doi.org/10.1111/j.1744-7909.2005.00035.x.

Yamamoto M., Chiba T. \& Tuji A. 2017. Salinity responses of benthic diatoms inhabiting tidal flats. Diatom Research 32: 243-250 DOI: 10.1080/0269249X.2017.1366951

Żelazna-Wieczorek J. 1996. Studium taksonomiczne rodzaju Vaucheria De Candolle oraz uwagi o występowaniu zidentyfikowanych gatunków tego rodzaju. Unpublished doctoral dissertation, University of Lodz, Poland.

Żelazna-Wieczorek J. 2002. Vaucheria species in selected regions in Poland. Acta Societatis Botanicorum Poloniae 71(2): 129-139.

Żelazna-Wieczorek J. 2011. Diatom flora in springs of Łódź Hills (Central Poland). In: Witkowski A., ed. Diatom monographs. Vol. 13. Ruggell, Liechtenstein: A.R.G. Gantner Verlag K.G. 419 pp.

Żelazna-Wieczorek J. \& Nowicka-Krawczyk P. 2015. The cascade construction of artificial ponds as a tool for urban stream restoration - The use of benthic diatoms to assess the effects of restoration practices. Science of the Total Environment 538: 591-599 DOI:10.1016/j.scitotenv.2015.08.110.

Żelazna-Wieczorek J. \& Olszyński R.M. 2016. Taxonomic revision of Chamaepinnularia krookiformis Lange-Bertalot et Krammer with a description of Chamaepinnularia plinskii sp. nov. Fottea, Olomouc 16(1): 112-121 DOI: 10.5507/fot.2016.001.

Żelazna-Wieczorek J., Olszyński R.M. \& Nowicka-Krawczyk P. 2015. Half a century of research on diatoms in athalassic habitats in central Poland. Oceanological and Hydrobiological Studies 441: 51-67 DOI: 10.1515/ohs-2015-0006.

Żurek R., Diakiv V., Szarek-Gwiazda E., Kosiba J. \& Wojtal A.Z. 2018. Unique Pit Lake Created in an Opencast Potassium Salt Mine (Dombrovska Pit Lake in Kalush, Ukraine). Mine Water and the Environment 37(3): 456-469 https://doi.org/10.1007/s10230-018-0527-z

Peer) reviewing PDF | (2019:05:37496:2:0:NEW 22 Oct 2019) 


\section{Figure 1}

Location of sampling points in the Łódzkie and Wielkopolskie voivodships. Poland.

A. Pełczyska (PE). B. Łęczyca (LE). C. Bogdałów (BO).

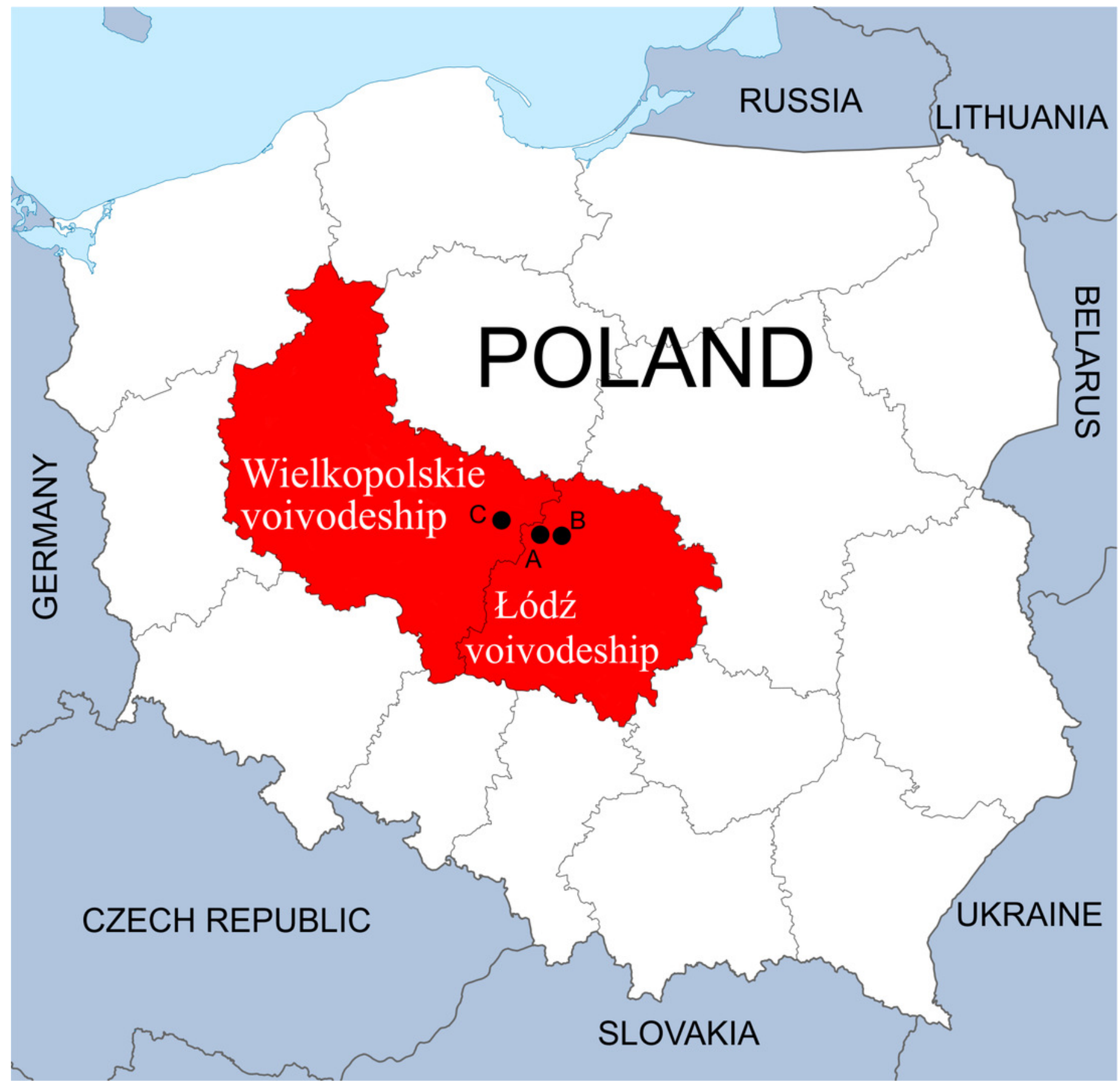


Figure 2

nMDS 3D analysis. The diagram shows three distinct clouds of samples which coincide with the three hydrological objects.

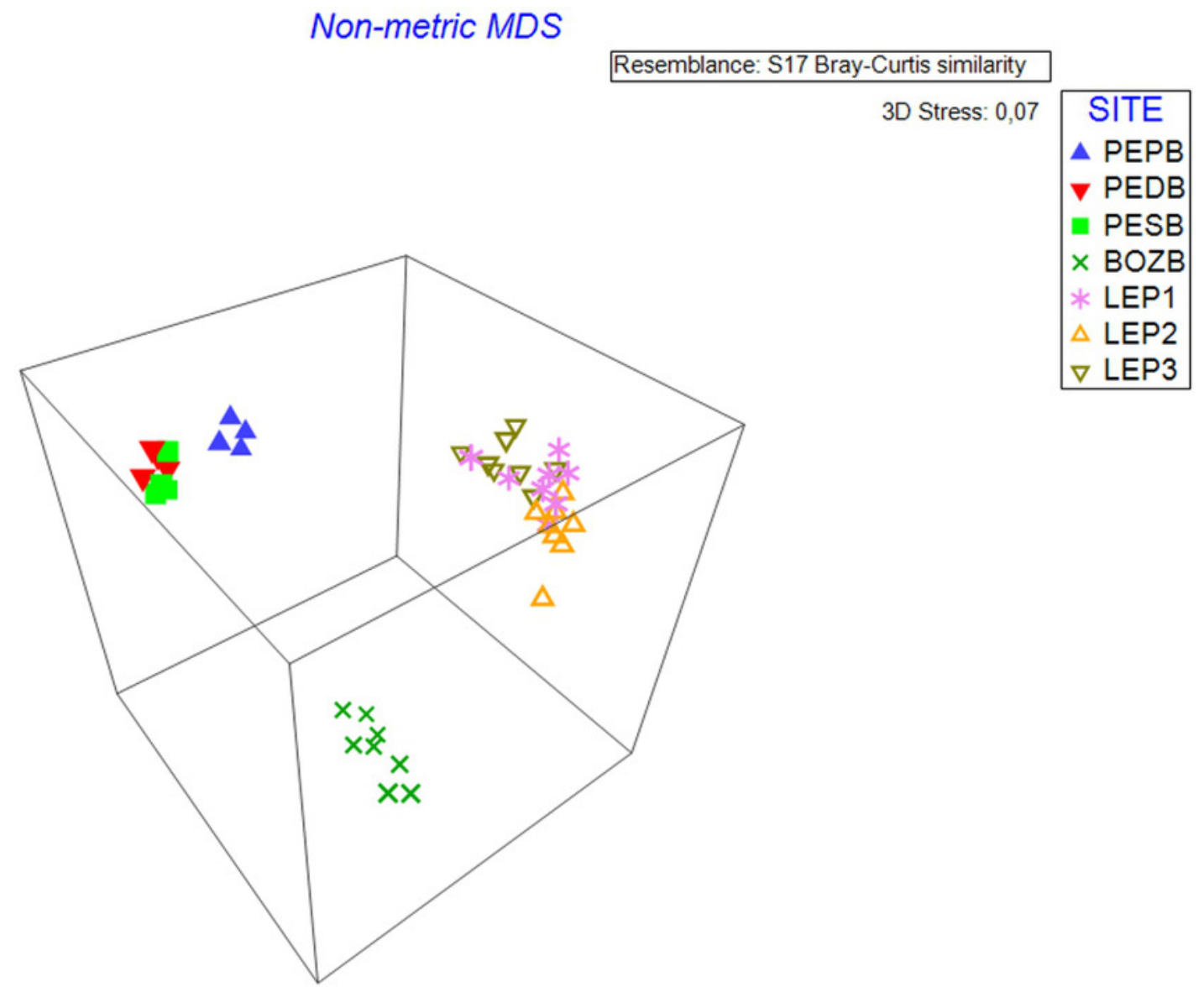


Figure 3

Shade Plot analysis. The diagram shows the strength of the factor (taxon) affecting the similarity between the samples.

Upper dendrogram - samples divided according to hydrological object. Left dendrogram - 50 taxa of diatoms which have the strongest influence on the similarity between the samples. 


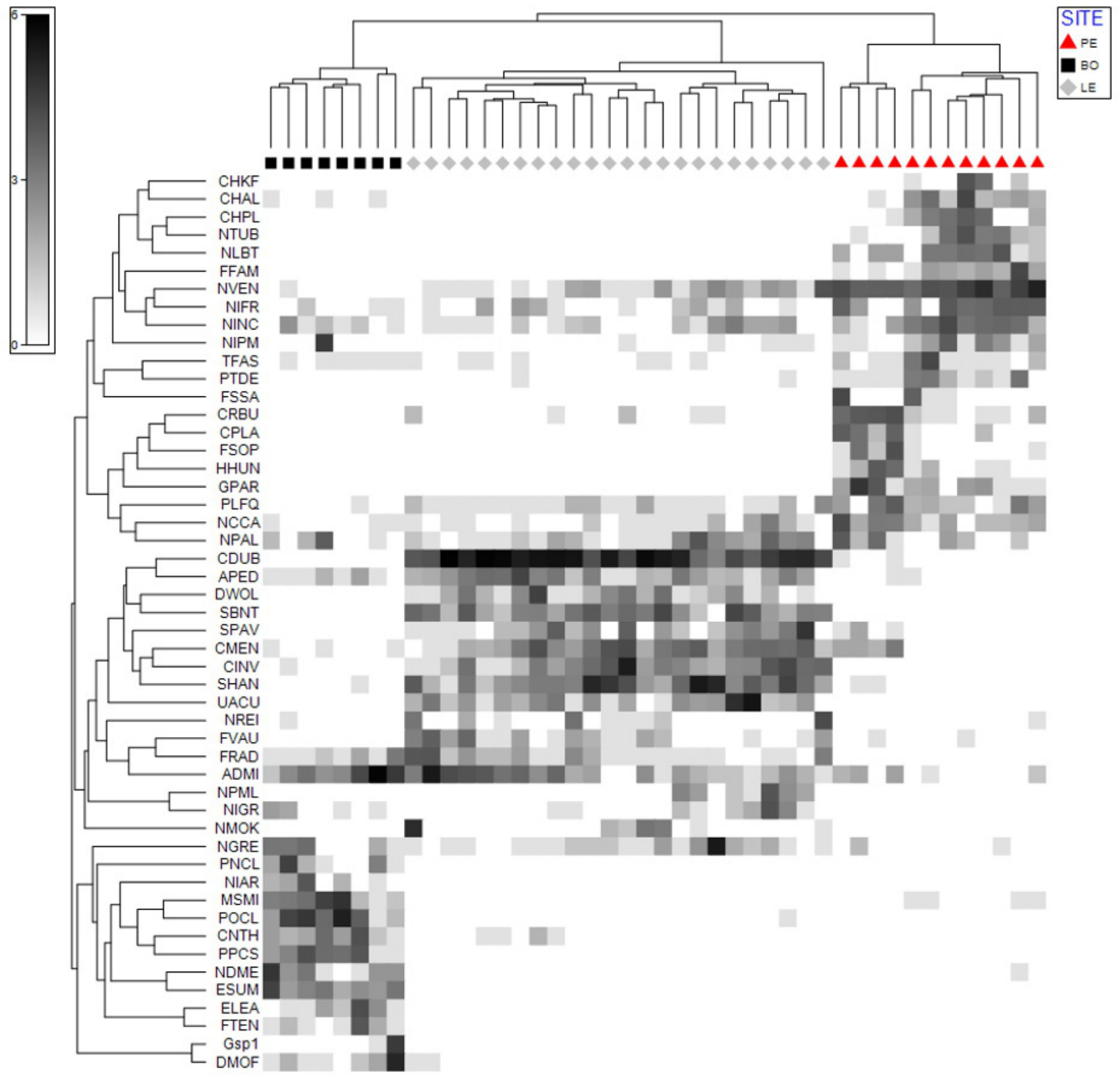


Figure 4

Principal Component Analysis.

The diagram presents three groups of species A, B and C, whose occurrence can be correlated with selected physical and chemical factors. 


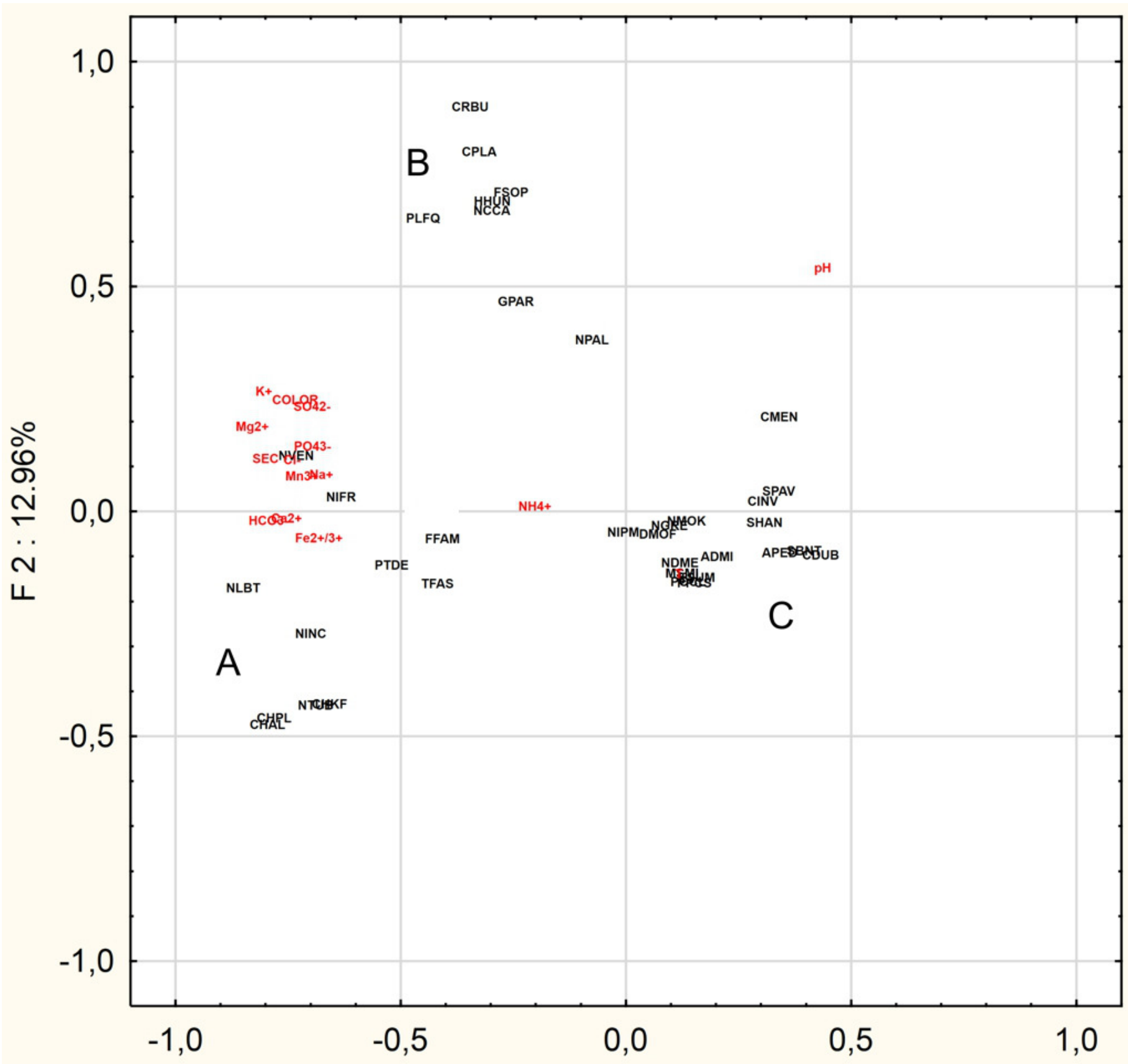

F $1: 18.35 \%$ 


\section{Figure 5}

LM microphotographs of characteristic diatom species.

A-E. Planothidium delicatulum. F-I. Chamaepinnularia krookiformis. J-M. Chamaepinnularia plinskii. N-Q. Nitzschia liebethruthii. R-U. Craticula buderi. V-Z. Navicula cincta. AA-FF. Planothidium frequentissimum. GG-JJ. Cyclostephanos invisitatus. KK-NN. Navicula moskalii. OO-RR. Stephanodiscus binatus. SS-VV. S. parvus. WW-AAA. Diatoma moniliformis. BBB-GGG. Encyonopsis subminuta. HHH-MMM. Mastogloia smithii (KKK-MMM. Same specimen, different focal plane). NNN-QQQ. Nitzschia dissipata var. media. RRR-XXX. Pantocsekiella pseudocomensis. Scale bar $=10 \mu \mathrm{m}$. 

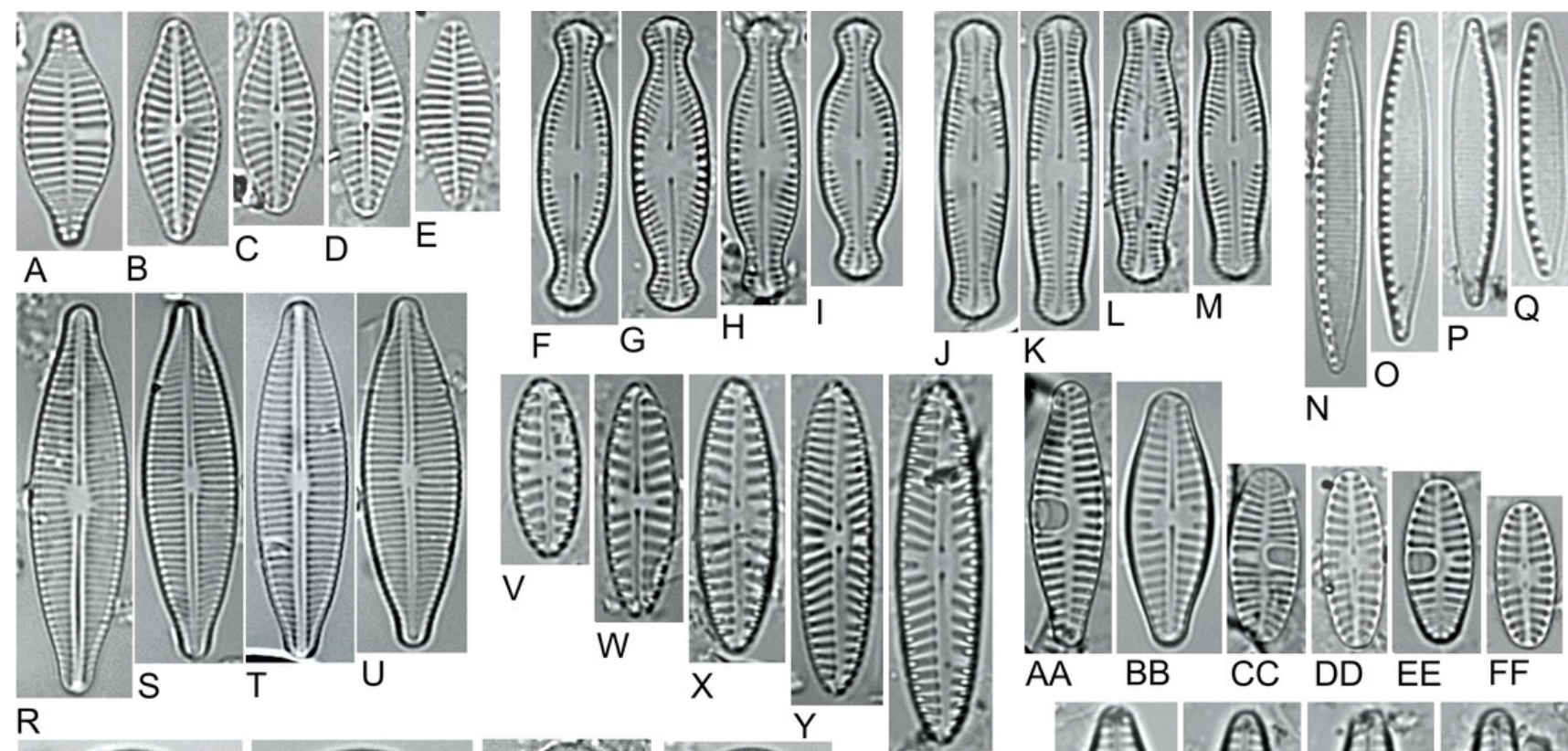

N

AA BB CC DD EE FF

$\mathrm{R}$
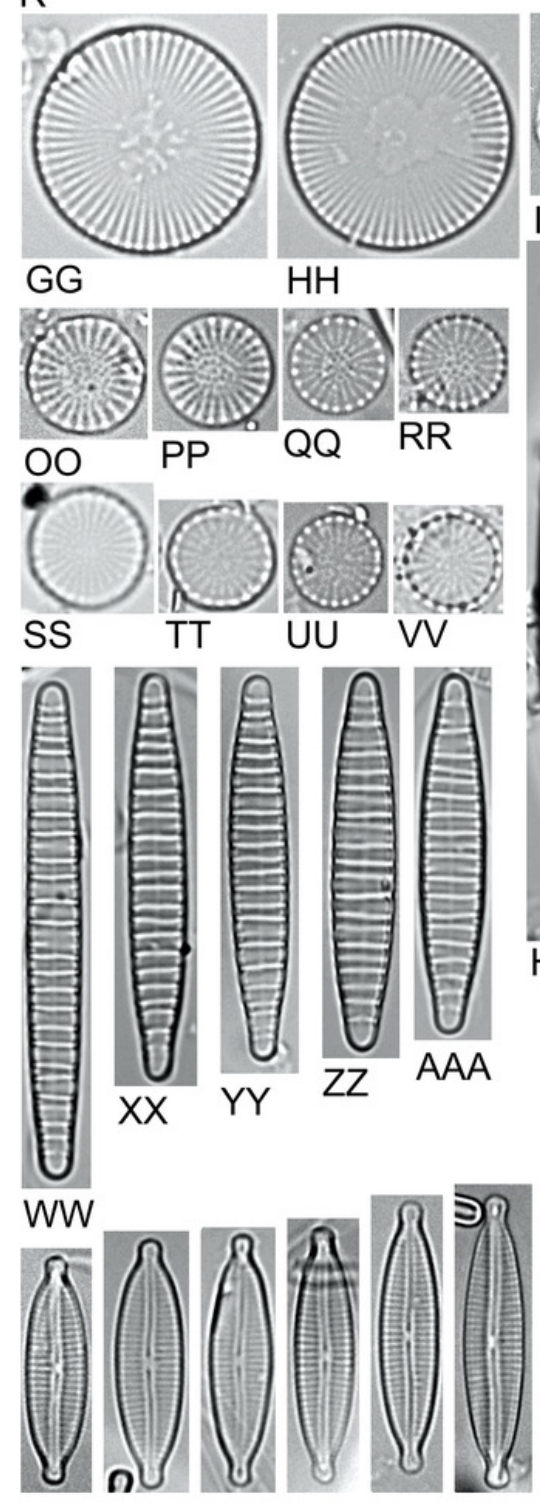

BBB CCC DDD EEE FFF GGG KKK
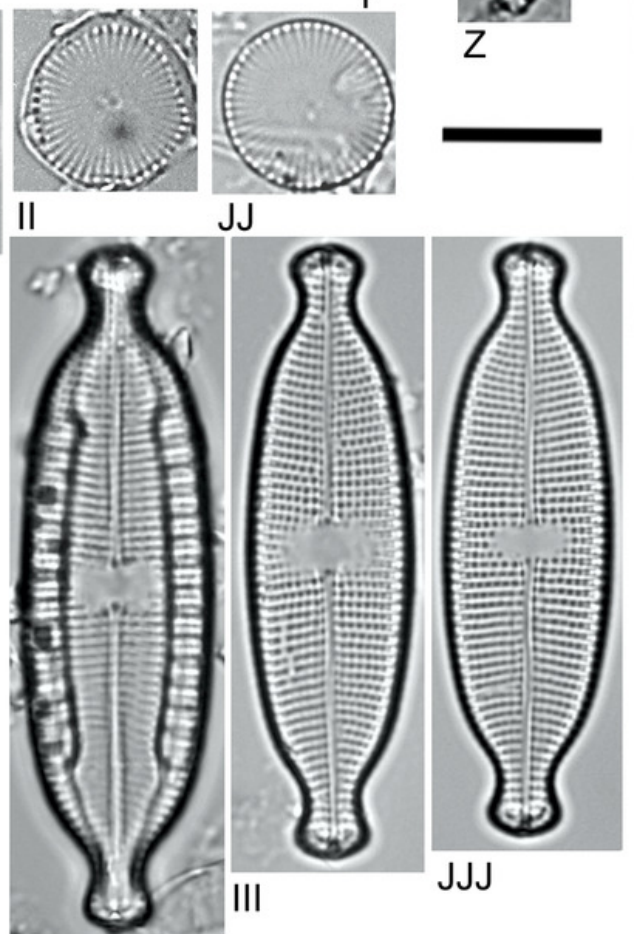

$\mathrm{HHH}$

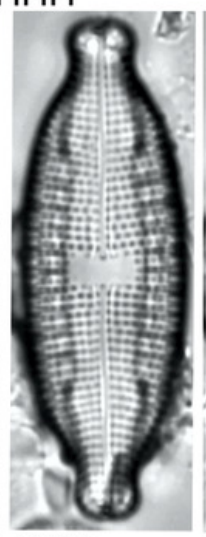

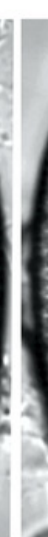

LLL
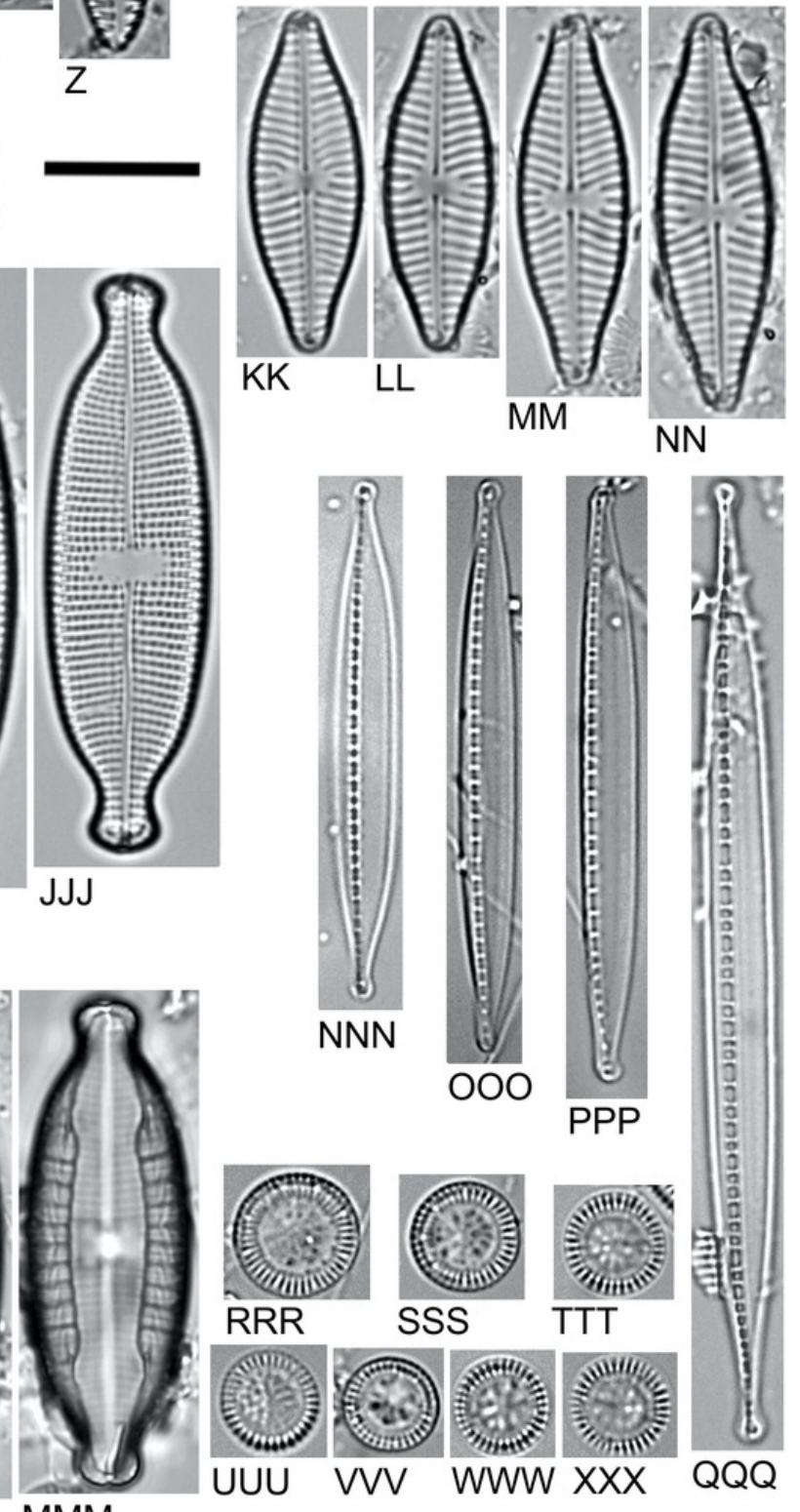


\section{Table $\mathbf{1}$ (on next page)}

Physical and chemical parameters in the examined sampling sites. The minimum, maximum and mean values. 


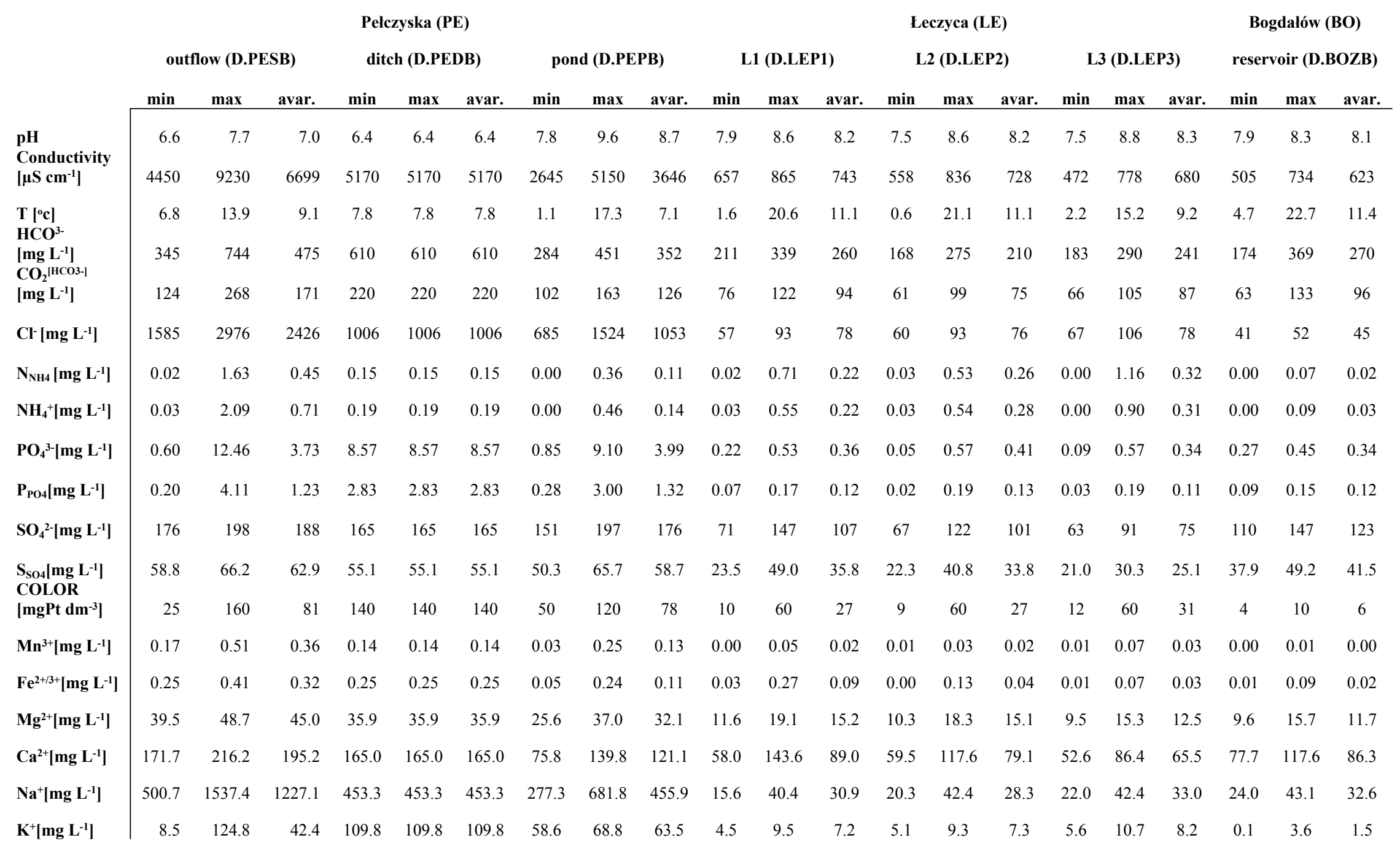




\section{Table 2 (on next page)}

Characteristic species according to SIMPER analysis for studied waterbodies.

EC - euconstant taxa, CN - constant taxa, CN - accessory taxa (Tümpling \& Friedrich 1999). 


\section{Pełczyska dich D.PEDB}

Chamaepinnularia krookiformis (AC)

Chamaepinnularia plinskii $(\mathrm{CN})$

Cocconeis placentula $(\mathrm{CN})$

Craticula buderi (EC)

Craticula halophila (EC)

Fragilaria famelica (EC)

Fragilaria sopotensis $(\mathrm{CN})$

Gomphonema parvulum (EC)

Hippodonta hungarica $(\mathrm{CN})$

Navicula cincta (EC)

Navicula veneta (EC)

Nitzschia frustulum (EC)

Nitzschia inconspicua (EC)

Nitzschia liebethruthii (EC)

Nitzschia palea $(\mathrm{CN})$

Nitzschia perminuta (EC)

Nitzschia tubicola $(\mathrm{CN})$

Planothidium delicatulum (EC)

Planothidium frequentissimum (EC)

Tabularia fasciculata (EC)
Lęczyca reservoirs LE

Achnanthidium minutissimum (EC)

Amphora pediculus (EC)

Cyclostephanos dubius (EC)

Cyclostephanos invisitatus (EC)

Cyclotella meneghiniana (EC)

Navicula gregaria (EC)

Navicula moskalii (AC)

Nitzschia palea (EC)

Stephanodiscus binatus (EC)

Stephanodiscus hantzschii (EC)

Stephanodiscus parvus (EC)

\section{Bogdałów reservoir BO}

Achnanthidium minutissimum (EC)

Diatoma moniliformis (EC)

Encyonopsis subminuta (EC)

Mastogloia smithii (EC)

Nitzschia dissipata var. media (EC)

Pantocsekiella ocellata (EC)

Pantocsekiella pseudocomensis (EC)

1 
Table 3 (on next page)

Characteristics species with classification of ecological indicators values by Van Dam et al. (1994). 


\begin{tabular}{|c|c|c|c|c|c|c|c|c|}
\hline Species & Code & 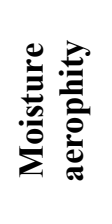 & 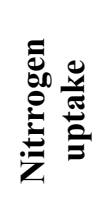 & 营莺 & 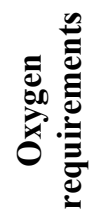 & : & 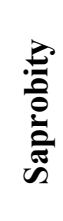 & 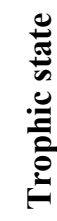 \\
\hline Achnanthidium minutissimum & ADMI & 3 & 2 & 3 & 1 & 2 & 2 & 7 \\
\hline Amphora pediculus & APED & 3 & 2 & 4 & 2 & 2 & 2 & 5 \\
\hline Chamaepinnularia krookiformis & $\mathrm{CHKF}$ & 3 & $\mathbf{0}$ & 3 & $\mathbf{0}$ & 3 & 1 & $\mathbf{0}$ \\
\hline Chamaepinnularia plinskii & CHPL & $\mathbf{0}$ & $\mathbf{0}$ & $\mathbf{0}$ & $\mathbf{0}$ & $\mathbf{0}$ & $\mathbf{0}$ & $\mathbf{0}$ \\
\hline Cocconeis placentula & CPLA & 2 & 2 & 4 & 3 & 2 & 2 & 5 \\
\hline Craticula buderi & CRBU & $\mathbf{0}$ & $\mathbf{0}$ & $\mathbf{0}$ & $\mathbf{0}$ & $\mathbf{0}$ & $\mathbf{0}$ & $\mathbf{0}$ \\
\hline Craticula halophila & CHAL & 2 & 2 & 4 & 2 & 4 & 3 & 5 \\
\hline Cyclostephanos dubius & CDUB & 1 & 2 & 5 & 2 & 3 & 3 & 5 \\
\hline Cyclostephanos invisitatus & CINV & $\mathbf{0}$ & $\mathbf{0}$ & $\mathbf{0}$ & $\mathbf{0}$ & 2 & $\mathbf{0}$ & 5 \\
\hline Cyclotella meneghiniana & CMEN & 2 & 3 & 4 & 5 & 3 & 4 & 5 \\
\hline Diatoma moniliformis & DMOF & $\mathbf{0}$ & $\mathbf{0}$ & $\mathbf{0}$ & $\mathbf{0}$ & $\mathbf{0}$ & $\mathbf{0}$ & $\mathbf{0}$ \\
\hline Encyonopsis subminuta & ESUM & $\mathbf{0}$ & $\mathbf{0}$ & 3 & 1 & 1 & 1 & 1 \\
\hline Fragilaria famelica & FFAM & 3 & 1 & 4 & 1 & 2 & 1 & 3 \\
\hline Fragilaria sopotensis & FSOP & 1 & 2 & 4 & 1 & 2 & 2 & 4 \\
\hline Gomphonema parvulum & GPAR & 3 & 3 & 3 & 4 & 2 & 4 & 5 \\
\hline Hippodonta hungarica & HHUN & 3 & 2 & 4 & 3 & 2 & 2 & 4 \\
\hline Mastogloia smithii & MSMI & 3 & $\mathbf{0}$ & 4 & $\mathbf{0}$ & 4 & 2 & $\mathbf{0}$ \\
\hline Navicula cincta & NCCA & $\mathbf{0}$ & $\mathbf{0}$ & $\mathbf{0}$ & $\mathbf{0}$ & 2 & $\mathbf{0}$ & 7 \\
\hline Navicula gregaria & NGRE & 3 & 2 & 4 & 4 & 3 & 3 & 5 \\
\hline Navicula moskalii & NMOK & $\mathbf{0}$ & $\mathbf{0}$ & $\mathbf{0}$ & $\mathbf{0}$ & $\mathbf{0}$ & $\mathbf{0}$ & $\mathbf{0}$ \\
\hline Navicula veneta & NVEN & 3 & 2 & 4 & 4 & 3 & 4 & 5 \\
\hline Nitzschia dissipata var. media & NDME & $\mathbf{0}$ & $\mathbf{0}$ & 4 & $\mathbf{0}$ & 2 & $\mathbf{0}$ & $\mathbf{0}$ \\
\hline Nitzschia frustulum & NIFR & 3 & 4 & 4 & 3 & 3 & 2 & 5 \\
\hline Nitzschia inconspicua & NINC & 3 & 3 & 4 & 3 & 3 & 3 & 5 \\
\hline Nitzschia liebethruthii & NLBT & $\mathbf{0}$ & $\mathbf{0}$ & 5 & $\mathbf{0}$ & 4 & $\mathbf{0}$ & $\mathbf{0}$ \\
\hline Nitzschia palea & NPAL & 3 & 4 & 3 & 4 & 2 & 5 & 6 \\
\hline Nitzschia perminuta & NIPM & 3 & 1 & 4 & 1 & 2 & 1 & 2 \\
\hline Nitzschia tubicola & NTUB & 2 & 3 & 4 & 4 & 3 & 5 & 6 \\
\hline Pantocsekiella ocellata & POCL & 1 & 1 & 4 & 1 & 1 & 1 & 4 \\
\hline Pantocsekiella pseudocomensis & PPCS & $\mathbf{0}$ & $\mathbf{0}$ & $\mathbf{0}$ & $\mathbf{0}$ & $\mathbf{0}$ & $\mathbf{0}$ & $\mathbf{0}$ \\
\hline Planothidium delicatulum & PTDE & 3 & 1 & 5 & $\mathbf{0}$ & 4 & 5 & 3 \\
\hline Planothidium frequentissimum & PLFQ & $\mathbf{0}$ & 2 & 4 & 3 & 2 & 4 & 7 \\
\hline Stephanodiscus binatus & SBNT & $\mathbf{0}$ & $\mathbf{0}$ & $\mathbf{0}$ & $\mathbf{0}$ & $\mathbf{0}$ & $\mathbf{0}$ & $\mathbf{0}$ \\
\hline Stephanodiscus hantzschii & SHAN & 2 & 3 & 5 & 4 & 2 & 4 & 6 \\
\hline Stephanodiscus parvus & SPAV & $\mathbf{0}$ & $\mathbf{0}$ & 5 & $\mathbf{0}$ & 2 & $\mathbf{0}$ & 6 \\
\hline Tabularia fasciculata & TFAS & 3 & 2 & 4 & 3 & 4 & 3 & 5 \\
\hline
\end{tabular}




\section{Table 4 (on next page)}

Selected 16 characteristic species with the new or altered (bold) ecological indicator values according to Van Dam et al. (1994). 
Species

Chamaepinnularia krookiformis

Chamaepinnularia plinskii

Craticula buderi

Cyclostephanos invisitatus

Diatoma moniliformis

Encyonopsis subminuta

Mastogloia smithii

Navicula cincta

Navicula moskalii

Nitzschia dissipata var. media

Nitzschia liebethruthii

Pantocsekiella pseudocomensis

Planothidium delicatulum

Planothidium frequentissimum

Stephanodiscus binatus

Stephanodiscus parvus

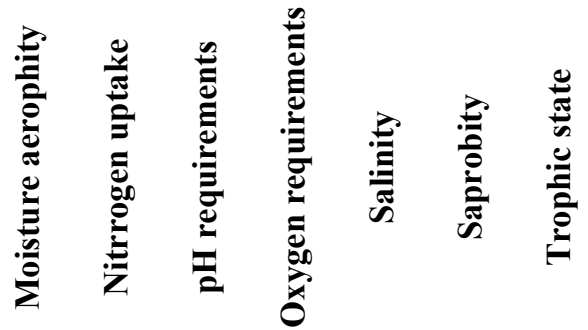

$\begin{array}{lccccccc}\text { CHKF } & 3 \mathbf{4} & 0 & 3 & 0 & \mathbf{3} \mathbf{4} & 1 \mathbf{4} & \theta \mathbf{5} \\ \text { CHPL } & \theta \mathbf{4} & 0 & \theta \mathbf{3} & 0 & \theta \mathbf{4} & \theta \mathbf{4} & \theta \mathbf{5} \\ \text { CRBU } & \theta \mathbf{3} & 0 & \theta \mathbf{4} & 0 & \theta \mathbf{4} & \theta \mathbf{4} & \theta \mathbf{5} \\ \text { CINV } & \theta \mathbf{1} & 0 & \theta \mathbf{4} & 0 & 2 & 0 & 5 \\ \text { DMOF } & 0 & 0 & 0 & 0 & 0 & 0 & 0 \\ \text { ESUM } & 0 & 0 & 3 & 1 & 1 & 1 & 1 \\ \text { MSMI } & 3 & 0 & 4 & 0 & 4 \mathbf{3} & 2 & 0 \\ \text { NCCA } & \theta \mathbf{3} & 0 & 0 & 0 & 2 & 0 & 7 \\ \text { NMOK } & 0 & 0 & \theta \mathbf{4} & 0 & \theta \mathbf{2} & 0 & \theta \mathbf{7} \\ \text { NDME } & 0 & 0 & 4 & 0 & 2 & \theta \mathbf{2} & 0 \\ \text { NLBT } & \theta \mathbf{4} & 0 & 5 \mathbf{3} & 0 & 4 & \theta \mathbf{4} & \theta \mathbf{5} \\ \text { PPCS } & 0 & 0 & 0 & 0 & 0 & 0 & 0 \\ \text { PTDE } & 3 & 1 & 5 \mathbf{3} & 0 & 4 \mathbf{5} & 5 & 3 \\ \text { PLFQ } & 0 & 2 & 4 & 3 & 2 & 4 & 7 \\ \text { SBNT } & 0 & 0 & \theta \mathbf{4} & 0 & \theta \mathbf{2} & 0 & 0 \\ \text { SPAV } & 0 & 0 & 5 \mathbf{4} & 0 & 2 & 0 & 6\end{array}$

